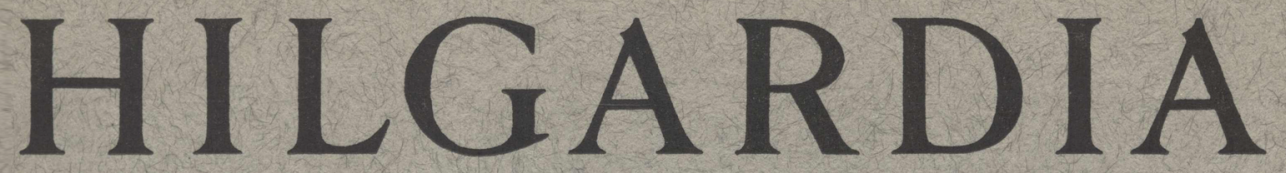

A Journal of Agricultural Science Published by the California Agricultural Experiment Station

\title{
THE SPOTTED ALFALFA APHID (YELLOW CLOVER APHID ON ALFALFA)
}

\author{
R. C. DICKSON, EDWARD F. LAIRD, JR., \\ and GEORGE R. PESHO
}


The spotted alfalfa aphid, Therioaphis maculata (Buckton), has become the most serious pest of alfalfa in many parts of southwestern United States since its discovery in New Mexico early in 1954.

Chiefly a pest of alfalfa, this insect also infests bur clover and sour clover. It does not live on red clover, Ladino clover, or sweetclover.

This insect damages alfalfa by ruining hay crops, by slowing regrowth, by thinning stands, and by killing seedling fields.

Spotted alfalfa aphid populations and resultant damage have been highest on the desert in the late fall, spring, and early summer. In cooler sections this aphid has done damage only in the summer and early fall.

The use of insecticides to control the spotted alfalfa aphid has not prevented ladybird beetles from doing a good job on this aphid when conditions were right, usually when the weather was warm. 


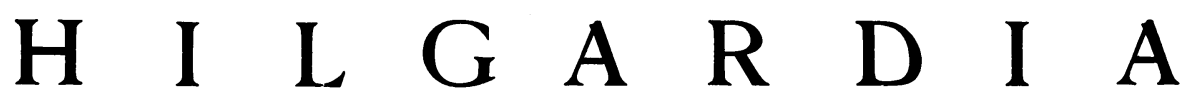

A Journal of Agricultural Science Published by

the California Agricultural Experiment Station

\begin{tabular}{lll}
\hline Vol. 24 & November, 1955 & No. 5 \\
\hline
\end{tabular}

\section{THE SPOTTED ALFALFA APHID \\ (Yellow Clover Aphid on Alfalfa)}

R. C. DICKSON, ${ }^{2}$ EDWARD F. LAIRD, JR., ${ }^{3}$ and GEORGE R. PESHO 4

\section{INTRODUCTION}

"Spotted alfalfa aphid" is the name now being established for the aphid infesting alfalfa that previously has been called "yellow clover aphid" in the United States and sometimes "lucerne aphid" in India. There is a yellow clover aphid in the United States but we now have reasonable evidence that the aphid infesting so much alfalfa in southwestern United States is distinct from it. Since these two species are distinct, they must have individual common names.

\section{SPREAD}

The spotted alfalfa aphid, Therioaphis maculata (Buckton), which has been confused with the yellow clover aphid, Therioaphis (Myzocallis) trifolii (Monell), was first found as an alfalfa pest in the United States in the spring of 1954. This aphid seems first to have damaged alfalfa in central and eastcentral New Mexico in February of 1954. On February 7, 1954, it was first taken in California, in east San Diego on bur clover, Medicago hispida, by R. F. Wilkey. It seems to have appeared on alfalfa in Arizona near Yuma sometime in May of 1954, but was not actually recognized and collected until June 8. On June 17 this aphid was seen in numbers at Bard, California, by Andrew S. Deal, but was not collected. On June 24, the spotted alfalfa aphid was found damaging about 700 acres of alfalfa at Orita, east of Brawley in the Imperial Valley. By this time it had been found in several locations in southern Arizona and in central and southern New Mexico. Early in July it was found near Blythe, California, and later in July was taken in small numbers in Oklahoma.

By September of 1954 the spotted alfalfa aphid had been found near Hemet, California. In October it appeared in the Coachella and Borrego

${ }^{1}$ Received for publication July 8, 1955.

${ }^{2}$ Associate Entomologist in the Citrus Experiment Station, Riverside.

${ }^{3}$ Senior Laboratory Technician, Department of Entomology in the Citrus Experiment Station, Riverside.

${ }^{4}$ Formerly Senior Laboratory Technician, Department of Entomology in the Citrus Experiment Station, Riverside. 
valleys in California, in the Moapa Valley in Nevada, and was widespread in Oklahoma. By November it had been found at Newberry in California's Mojave Desert, and at Torreon, Coahuila, Mexico. Sometime in the fall it was taken in southeastern Colorado. In December it appeared near Santa Ana and Lancaster, California, and in the Texas panhandle. In January of 1955, it was found near Edison in Kern County, California. By March it was heavy in north-central Texas and south-central Oklahoma. In early April this aphid had spread to the northern border of Oklahoma where it was reported heavy by early May. It was recorded in Fresno County, California, on April 13. By mid-May it had reached the Wichita area in southcentral Kansas. At this time "yellow clover aphid" was reported on red, alsike, and white clovers in Nebraska, but this record seems to refer to two distinct but similar species. By late May, alfalfa was heavily infested in a triangular area in south-central Kansas and had appeared in southwestern Utah.

From these records the spotted alfalfa aphid infesting alfalfa appears to be a new pest to the United States. It has acted like a newly arrived species that was introduced into central New Mexico sometime in the summer or fall of 1953. From this center it has spread rapidly in all directions to become a severe pest of alfalfa over a large part of the dry, hot portion of southwestern United States. The identity of the spotted alfalfa aphid will be discussed more fully in a section below. The arrival of a foreign species in an inland area such as central New Mexico could be traceable to modern aircraft which have made any airport as vulnerable as a seaport.

\section{HISTORY}

Kaltenbach $(1846)^{5}$ described the first aphid recorded in the Therioaphis group. This was Aphis ononidis Kalt., from restharrow, Ononis spinosa, in Europe. Passerini (1863) used the name Myzocallis ononidis (Kalt.) for aphids found on Ononis, clover, and alfalfa in Italy.

Monell (1882) described Callipterus trifolii Monell from specimens taken on red clover at Washington, D.C. This provides the specific name that has been commonly used in the United States for all members of the yellow clover group found in this country.

Osborn and Sirrine (1893) reported $C$. trifolii Monell abundant on red clover in Iowa in the autumn.

Buckton (1899) described Chaitophorus maculatus Buckt. from alfalfa at Jodhpur, India, from specimens collected in March, 1897. Sanborn (1906) described Callipterus genevei from a specimen taken "on the wing" in Kansas. This seems to be a synonym of trifolii Monell.

Davis (1908) reported the yellow clover aphid common on red clover in all parts of Illinois. He also stated that it had been reported authentically from New York, Virginia, Minnesota, North Dakota, Kansas, and Missouri. Folsom (1909) stated that the yellow clover aphid was common on clover, but not destructive in Illinois, and added Delaware to the list of infested states given by Davis the previous year. He reported work done by R. L. Webster, indicating a maximum of 19 generations per year. Time from birth to

\footnotetext{
"See "Literature Cited" for citations, referred to in the text by author and date.
} 
maturity was given as 5 to 24 days with 7 to 10 days generally required in the summer. Young production ranged from 6 to 75 with an average of 34.8 per female. Davis (1910) simply listed the yellow clover aphid as on clover, but of no importance. Gillette (1910) listed the aphid from Michigan.

J. J. Davis (1914) published the most comprehensive work ever done on the yellow clover aphid. He reported distribution and host plants, described the various forms of the aphid and detailed a large life history study. His work indicated a maximum of 17 possible generations per year at Lafayette, Indiana. His results were similar to those reported by Folsom (1909): 6 to 16 days (average 9.1 ) from birth to maturity, 10 to 99 (average 50) young per female at an average rate of 3.2 per day.

Theobald (1915) listed a yellow clover aphid as attacking berseem, Trifolium alexandrinum, in Egypt. The aphids he worked with were collected by Willocks who reported that they produced great quantities of honeydew. Das (1918) reported an aphid of this group widely distributed in India on alfalfa and berseem, and on various species of Medicago. In the Punjab it was reported to be a pest of alfalfa from March to May. Theobald (1923) reported an aphid of this group on Ononis reclinata in England. We now assume this aphid to be ononidis Kalt. Hall (1926) lists a "yellow clover aphid" as a pest of berseem in Egypt. Theobald (1927) lists yellow clover aphids in Britain on Ononis and Trifolium only, not on alfalfa. Hottes and Frison (1931) reported the yellow clover aphid as taken only on Trifolium procumbens and $T$. pratense in Illinois. They did not report it on alfalfa.

Nevsky (1929) reported that an aphid of this group "lives on lucerne wherever this plant is found in central Asia." DeLepiney and Mimeur (1932) reported it on alfalfa in Morocco, and Tsing and Tao (1936) reported it on alfalfa in Shantung province, China.

\section{IDENTITY}

It is evident from the published records above that all of the "yellow clover" aphids (genus Therioaphis) reported from various places did not act alike. This is shown strongly by the host records in table 1 . This table is compiled from publications, from work reported in this paper, and from material recently collected or identified by Louise M. Russell of the Insect Identification and Parasite Introduction Section, Entomology Research Branch, United States Department of Agriculture. The European records in the table are from Börner (1952).

The scientific names used for aphids of this group have been confused. The specific name maculata Buckton has almost always been considered a synonym of trifolii Monell, which has often been considered a synonym of ononidis Kaltenbach. Recent events have focused interest on this group, which has resulted in intensive work that is still going on.

As a result of this work it is now reasonably probable that there are at least four species in this group. These are:

Therioaphis ononidis (Kalt.), an aphid that lives on plants of the genus Ononis (O. spinosa, O. repens) in Europe and Africa. This species is morphologically distinct from others of the group that we have seen. Its rostrum is longer and the markings on the abdomen are distinctive. 


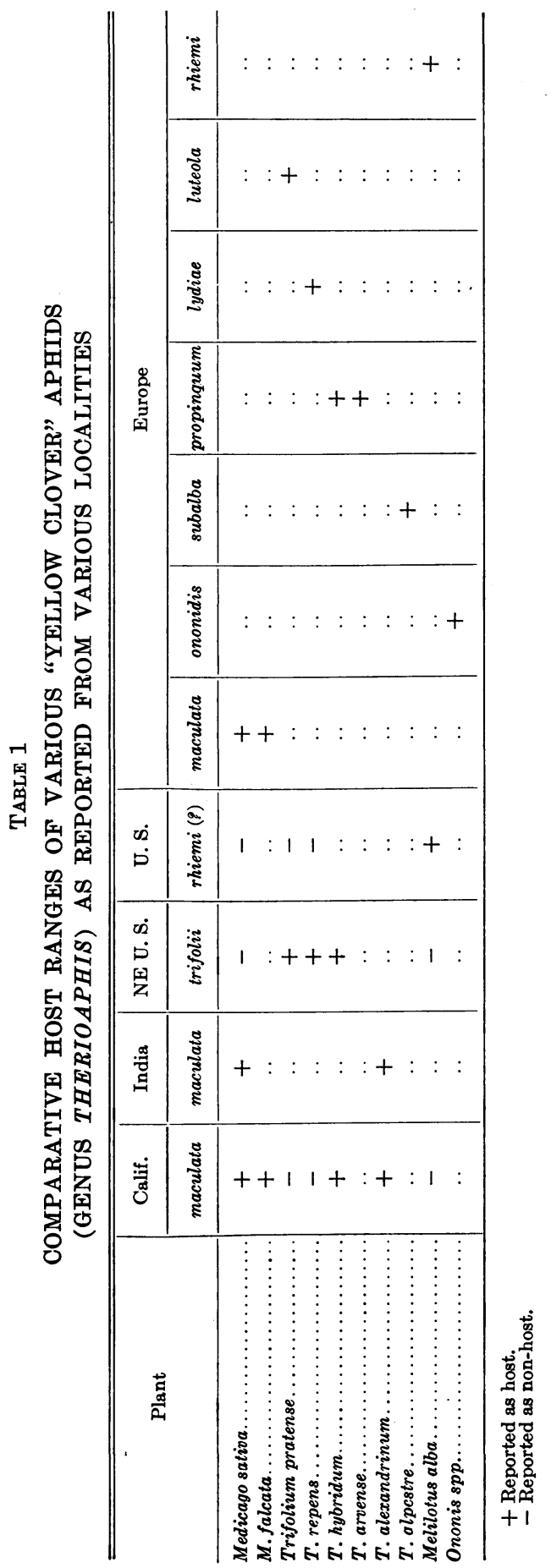


Therioaphis trifolii (Monell), the true yellow clover aphid, prefers clovers, especially Trifolium pratense and T. repens. This species was described from Washington, D.C., but was very probably introduced from Europe, Asia, or Africa, more than seventy-five years ago. This is the aphid that has been present in northeastern, middle-western, and southern United States for many years as a minor pest of clovers. It has not been a pest of alfalfa.

Therioaphis maculata (Buckton) is the spotted alfalfa aphid or "yellow clover aphid" on alfalfa and probably on berseem. It is the aphid written up in this paper. This species was described from India in 1899 from specimens taken on alfalfa near Jodhpur. This species differs slightly but significantly from $T$. trifolii in its appearance. T. maculata averages fewer sensoria on antennal segment III than does $T$. trifolii. An even better character to separate the 2 species is the relative distance the sensoria extend out from the base of antennal III. Measurements of thirty antennae of alate $T$. trifolii from Trifolium showed that the sensoria covered $64.65 \pm 5.69$ per cent of III while measurements of 101 antennae from alate T. maculata from Medicago gave $45.52 \pm 2.09$ per cent for the same character. Specimens received from alfalfa in Italy and Israel fell nicely within the range shown by T. maculata in southwestern United States. This character is strongly reinforced by evidence from host range and distribution.

Therioaphis maculata seems to be the aphid that has been reported on alfalfa in Europe and India and around the Mediterranean. It is possible that $T$. maculata is only the "alfalfa" variety of $T$. trifolii and that it mutated from the "clover" variety in central New Mexico, but this appears unlikely. It is improbable that such a mutation and establishment would occur in New Mexico, where the clover form was either very rare or nonexistent, rather than in the Midwest where large populations of cloverpreferring $T$. trifolii have been exposed to alfalfa for at least thirty years. It is faintly possible that the spotted alfalfa aphid is a still undescribed species.

There is a species on sweetclover, Melilotus alba, and on M. officinalis, that may be Therioaphis rhiemi (Börner). The presence of this aphid in that area of the United States extending from the eastern seaboard to Nebraska and Kansas was brought to light by Louise Russell who found it in the field and in certain collections. It has also been found recently in New Mexico, Colorado, Utah, Idaho, and Oregon. This species is rather easily distinguished from the other species of Therioaphis in the United States by the presence of fewer sclerotized areas on the dorsum of the abdomen and by smaller dorsal setae. The discovery of this aphid explains recent reports of the "yellow clover aphid" on sweetclover in Kansas and Nebraska.

It is not possible at the present time even to guess at the status of Börner's other 4 European species (subalba propinquum, lydiae, luteola), although it is probable that at least one of them is a synonym of trifolii Monell. It is reasonably probable that genevei Sanborn (1906) is a synonym of trifolii Monell.

The official name of the yellow clover aphid in the United States is Myzocallis trifolii (Monell). In addition to Myzocallis Passerini, generic names that have been applied to "yellow cover" aphids in recent years are: Callipterus Koch, Therioaphis Walker, Triphyllaphis Börner, Pterocallidium 
Börner, and Myzocallidium Börner. Callipterus Koch is preoccupied and has been replaced by Panaphis Kirkaldy. The yellow clover aphids do not seem to belong in Panaphis but rather in the Myzocallis group of species. If large genera are preferred the yellow clover aphids belong in Myzocallis, where they would form a distinct group of subgenus. Splitting Myzocallis a bit would place the four (or more) species infesting clovers and related legumes in Therioaphis. Certainly there is no excuse for splitting them any further. Since the species are distinguishable with difficulty they should not be separated into different genera. Whether to use Myzocallis or Therioaphis for ononidis (Kalt.), maculata (Buckt.), trifolii (Monell), and possibly rhiemi (Börner) will remain a matter of individual preference and has no biological significance. The recognition of maculata (Buckt.) as the correct name for the "yellow clover aphid" infesting alfalfa calls for a new common name and "spotted alfalfa aphid" has been used for it in this paper. It is sincerely hoped that this new common name can be established in general usage for Therioaphis maculata (Buckton).

\section{DAMAGE}

Feeding by the spotted alfalfa aphid injures the alfalfa plant. Aphids insert the stylets of their mouth parts into the host plant and extract juice while feeding. At the same time they inject saliva into the plant. This saliva may be relatively innocuous or it may be toxic to the plant. It appears that the saliva injected by the spotted alfalfa aphid is somewhat toxic.

The most conspicuous damage done by the spotted alfalfa aphid to alfalfa is to the hay crop. In warm weather this aphid congregates on the lower leaves. These leaves are killed, dry up, and may fall from the plant. As the lower leaves are killed, the aphids move up the stem, infesting and killing higher leaves until only a tuft of leaves may be left at the top of a bare stem. In the meantime, the aphids have excreted large quantities of honeydew (liquid excrement) that is high in sugars so that the plants are coated with a sweet syrup. Under certain conditions sooty mold fungus grows in the honeydew, covering the alfalfa plant with a black, powdery deposit. While the honeydew itself is full of sugars and is good feed it makes harvesting very difficult. Mowers and rakes may become so covered with the sticky honeydew that it is necessary to wash them periodically to harvest the alfalfa. Baling may be almost impossible and several balers have burst at the bottom while working on sticky hay. It may be necessary to bale only on hot afternoons when the honeydew is less sticky. This usually results in chopping the hay into chaff, further lowering the grade. Populations of 40 aphids per stem will begin to cause stickiness on growing alfalfa 8 to 18 inches high.

The spotted alfalfa aphid slows the growth of its host plant. This is often difficult to see since the rate of growth of alfalfa varies from field to field and from cutting to cutting. It is most conspicuous where a streak or a corner has been skipped during an insecticide application. Extreme examples of growth retardation occur after a field that has a high aphid population and few predators is cut. The aphids congregate on the stubble and move to the new shoots as the alfalfa starts regrowth. These shoots may be com- 
pletely shingled by spotted alfalfa aphids and may stop growing entirely when about 1 inch long.

Figure 1 shows growth in a field that was not treated until 14 days after

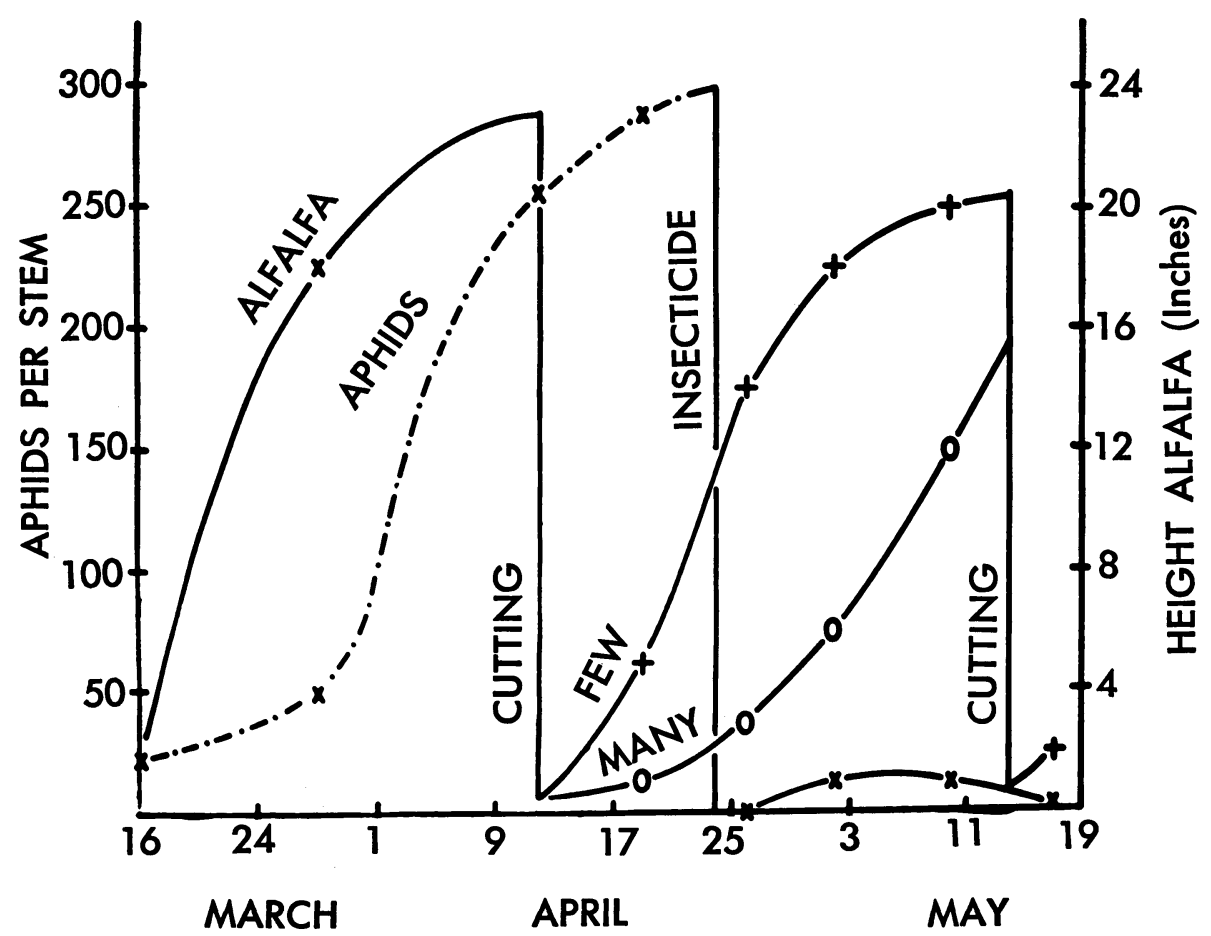

Fig. 1. Growth of alfalfa in a field near Brawley. Growth after April 11 cutting shown for plants covered by spotted alfalfa aphids and for plants relatively free from them.

harvest. This field had a fairly high aphid population before cutting. It also had a few ladybird beetle larvae. After cutting, the aphids covered the growing shoots. There were enough ladybird larvae to clean up fairly well about one fifth of the shoots while the rest remained shingled by spotted alfalfa aphids. The line marked "few" measures the growth of those shoots that had been partially freed from aphids while the "many" line shows the growth on which the aphids were undisturbed. It is probable that the growth of those stems, partially cleaned by ladybirds, was materially slowed by aphids since growth was not so rapid as that of the previous cutting. There was additionally a considerable mortality among the more heavily infested plants.

Stand-thinning is another part of the damage done to alfalfa. A single, very heavy infestation may ruin a stand but more commonly untreated fields gradually thin out faster than normal so that a stand will be good for, say, two years instead of three.

Alfalfa plants that are not growing because of drought or cold weather may be killed by spotted alfalfa aphid feeding. It is not safe to ignore a heavy aphid population on the ground that the alfalfa "wouldn't grow 
even if it didn't have any aphids on it." It appears that an important factor in stand-thinning is the invasion of the roots of weakened plants by soil fungi.

Seedling alfalfa is especially susceptible to fatal injury by the spotted alfalfa aphid. Very small seedlings may be killed by single aphids. Injurious populations sometimes appear very quickly in a seedling field by flight from nearby mature fields that are heavily infested. One place where the death of alfalfa seedlings is often not noticed is in mature stands. Intentional or accidental seeding of these fields is important to thicken the stand for the following season. The little seedlings are so inconspicuous, their loss is readily overlooked.

\section{STUDY METHODS}

Shortly after the discovery of the spotted alfalfa aphid in Imperial Valley in late June, 1954, a population study was started that has continued until the time of this writing in June, 1955. Fifty-two fields were originally set up as sampling stations, distributed over the entire Imperial Valley. Many have been sampled for a full year, but others have been plowed out. In some instances nearby fields were selected as sampling stations to replace those lost. At least 43 fields have been covered at each sampling.

Spotted alfalfa aphids were sampled by counting the number found on 20 stems at about the same location in the field each time. Predator populations were sampled by 10 standard $\left(180^{\circ}\right)$ sweeps with an insect net. To determine actual field populations from the samples a circular wire frame with an area of 1 square foot was cast at random into alfalfa fields and the number of stems it enclosed counted. This was done 141 times and gave an average count of 42.2128 stems per square foot. This is equivalent to $1,838,790$ stems per acre and indicates that for each aphid found on the 20 stem sample there were, on the average, 91,939 aphids in 1 acre.

To relate the aphid populations to the predator populations, we recorded the number of ladybirds and the number of Orius seen on the 20-stem samples. Not surprisingly, the figures obtained for the 2 predator groups were rather different. They showed that 10 sweeps caught ladybird beetles equivalent to the number found on 303.946 stems and that 10 sweeps caught Orius equivalent to the number on 906.667 stems. This meant that 1 ladybird caught in 10 sweeps indicated 6,050 ladybirds per acre. One Orius caught in 10 sweeps similarly indicated 2,028 per acre. It is probable that these figures are relatively inaccurate, but at least by their use it is possible to get some picture of insect populations in an alfalfa field.

This population study was supplemented by routine life history studies conducted from time to time in screen cages in an alfalfa field throughout the winter, spring, and early summer.

\section{PLANT HOSTS}

All the "yellow clover" aphids seem to be restricted to a relatively few species of the pea family. Tests of a number of clovers and related plants as hosts of the spotted alfalfa aphid from alfalfa were made in the greenhouse at Riverside. Later, certain of these host plants were observed in the field at Meloland. The plants in the greenhouse were infested by scattering 
aphids over them, while those in the field were naturally infested by aphids flying from a nearby alfalfa field. In neither case were the plants caged. Results of these tests are shown in table 2. A plant species was considered

TABLE 2

RESULTS OF TESTS OF SEVERAL LEGUMES AS HOSTS OF THE SPOTTED ALFALFA APHID. FIELD TEST RECORDS INDICATE RELATIVE SUITABILITY AS HOST

\begin{tabular}{|c|c|c|c|}
\hline \multicolumn{2}{|c|}{ Names } & \multirow{2}{*}{ Greenhouse } & \multirow{2}{*}{ Field } \\
\hline Common & Scientific & & \\
\hline Alfalfa. & Medicago sativa... & + & +++ \\
\hline Black medic............... & M. lupulina.............. & + & $\ldots$ \\
\hline Cal. bur clover............ & M. hispida......... & + & +++ \\
\hline Yellow-flowered alfalfa.. & M. falcata.... & + & $\ldots$ \\
\hline Barred medic............. & n............. & .. & +++ \\
\hline Red clover..... & Trifolium pratense.... & - & - \\
\hline Strawberry clover... & T. fagiferum............. & + & $\ldots$ \\
\hline Crimson clover........ & 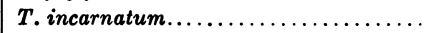 & + & + \\
\hline White Dutch clover......... & T. repens................... & - & $\ldots$ \\
\hline Ladino clover.............. & 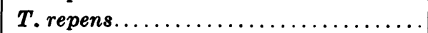 & - & $\ldots$ \\
\hline Alsike clover. . & 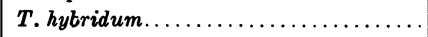 & + & $\ldots$ \\
\hline Rose clover.......... & 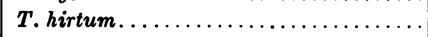 & - & - \\
\hline Berseem $\ldots \ldots \ldots \ldots \ldots \ldots \ldots \ldots \ldots$ & 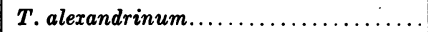 & ? & + \\
\hline Subterranean clover................ & 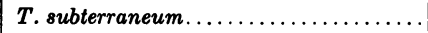 & - & - \\
\hline Yellow-blossom sweet clover........... & Melilotus officinalis.................. & + & + \\
\hline Hubam clover................ & M. alba annua............... & - & - \\
\hline Sour clover............... & $M$. indica $\ldots \ldots \ldots \ldots \ldots \ldots$ & + & ++ \\
\hline Common vetch.... & Vicia villosa ............. & - & - \\
\hline Purple vetch.... & V. atropurpurea........... & - & $\ldots$ \\
\hline Birdsfoot trefoil. & Lotus corniculatus...... & - & - \\
\hline Sesbania............. & Sesbania macrocarpa................ & .. & - \\
\hline
\end{tabular}

+ Reproduced on host. The greater the number of + , the greater the reproduction on the host.

Did not reproduce on host.

to be a host only if spotted alfalfa aphids established themselves on it and reproduced. Five varieties of alfalfa, 5 of subterranean clover, 2 of crimson clover, and 3 of birdsfoot trefoil were tested without revealing any varietal variation, so varietal names are not included. There is a doubt as to the results of these tests on Hubam clover, Melilotus alba annua. While they seemed conclusive enough, Dr. Wayne Howe found in his tests that spotted alfalfa aphids reproduced reasonably well on this plant. The only apparent difference in the tests was that he caged his plants while ours were left open.

Alfalfa, bur clover, and medic seemed to be the preferred hosts. They became completely covered by aphids and some plants were killed unless treated with an insecticide. Sour clover was almost as good a host. Others were relatively poor. A field of berseem was observed to have only a light infestation of reproducing aphids on the lower leaves, even though it was adjacent to heavily infested alfalfa.

As shown in table 1, the host range of our "alfalfa" aphid differs from that reported for the "clover" aphid in northern and eastern United States. A third host group is shown for the "sweetclover aphid," T. rhiemi. Davis (1914) reported that Melilotus spp. were not hosts of $T$. trifolii. He probably tested Melilotus alba. In Nebraska in June, 1955 (Co-operative Insect 
Reports), "white clover," Melilotus alba, was reported to be a host to a yellow clover aphid. It has been shown very recently that this "yellow clover" aphid on sweetclover is a distinct species. While the commercial varieties of alfalfa grown in the desert areas of southwestern United States do not show any appreciable resistance to the spotted alfalfa aphid, certain northern varieties, notably Lahontan, are said to show marked resistance. The field berseem which was found infested was the Miskawi variety.

The clovers found to be nonhosts of the spotted alfalfa aphid are of no importance as forage crops in desert southern California. Ladino clover, however, is an important ingredient in the mixtures sown in irrigated pastures under slightly cooler conditions.

Summing up, our spotted alfalfa aphid lived well on all species of Medicago tested, did fairly well on 2 of the 3 species of Melilotus, and did poorly to fairly on 4 of the 8 species of Trifolium.

The differences in host range between the spotted alfalfa aphid from alfalfa, and the yellow clover aphid from clover, as shown in table 1, are important in deciding taxonomic relationships. Our spotted alfalfa aphid does not act like the yellow clover aphid that has been present in northern and eastern United States for many years. It acts like a distinct species.

\section{LIFE HISTORY}

The spotted alfalfa aphid shows the life history pattern common to aphids in hot climates. Both apterous and alate parthenogenetic females are present throughout the year. These produce young without mating, at rates determined by the temperature and by the condition of the host plant. In midwinter, a few apterous oviparous females are found, but we found no evidence that they laid eggs. We did not find males, but they were probably present.

Routine life history studies were conducted during the winter of 1954-55 at Riverside, and during the spring and early summer of 1955 at Meloland, near Holtville. The cages used are shown in figure 2. They were made of 32- $\times$ 32-inch mesh plastic screen fastened over metal frames and held to the wooden base by springs. The base of each cage was ringed by a strip of foam rubber that fitted snugly against a similar ring fastened to the base. The alfalfa stem was inserted into the cage through a hole drilled through the wooden base. Smaller holes drilled in the base were used to hold $3 / 8$-inch dowels that were driven into the ground to hold the whole assemblage in place.

The studies were conducted in two parts. One started with newly born nymphs and carried these through to maturity. The other started with recently molted adults and carried these through their period of reproduction.

To obtain newly born nymphs, two adult aphids were placed in each of 11 cages and left until they had produced a few, usually 2 to 7 nymphs. The adults were then removed and the nymphs checked from time to time to catch them at maturity. The results are shown in table 3 . By the time experiments were started early in November, 2 to $2 \frac{1}{2}$ weeks were required for nymphal development. Nymphs born late in November required about 3 weeks to mature. At this time, the spotted alfalfa aphid was not a severe pest, except on seedling alfalfa. 


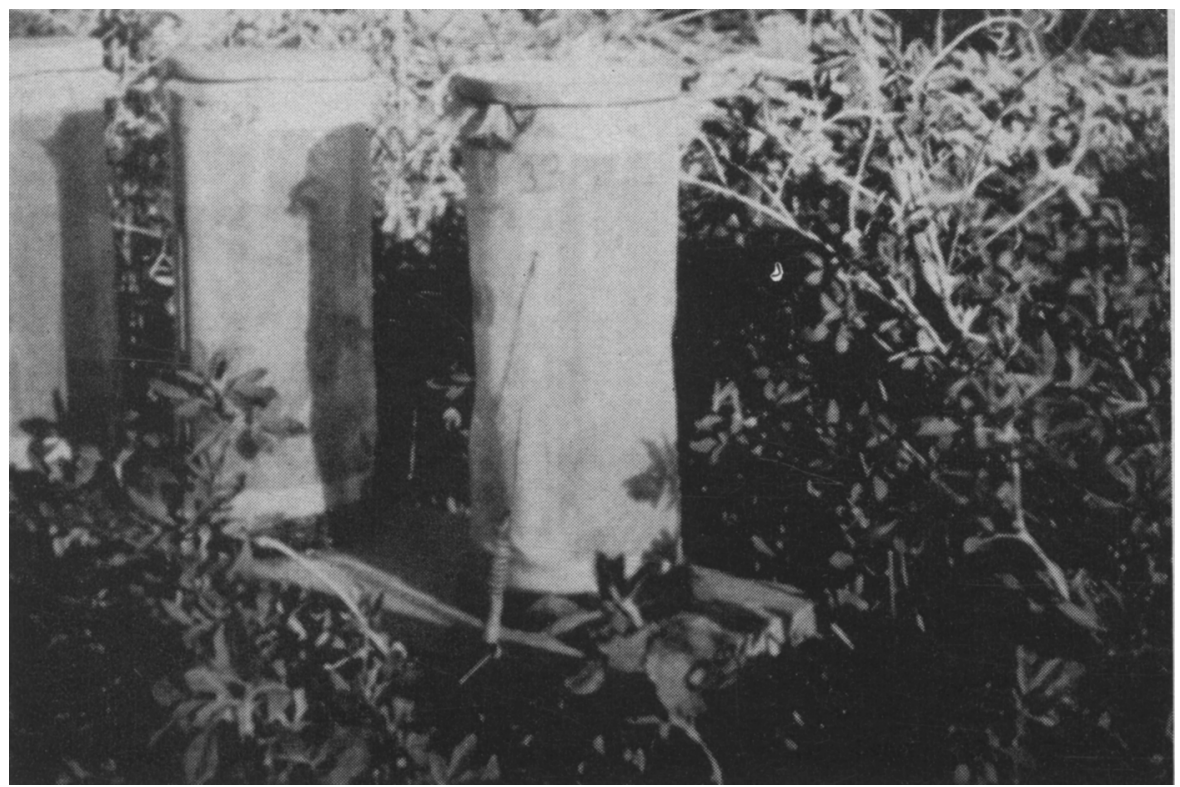

Fig. 2. Cages used in life history studies of the spotted alfalfa aphid on alfalfa, Meloland, California, May, 1955.

TABLE 3

ELAPSED DAYS FROM BIRTH TO MATURITY FOR SPOTTED ALFALFA APHIDS BORN ON THE DATES SHOWN

\begin{tabular}{|c|c|c|c|c|c|}
\hline \multirow{3}{*}{ Days to maturity } & \multicolumn{5}{|c|}{ Dates of birth } \\
\hline & \multicolumn{3}{|c|}{ Riverside (1954) } & \multicolumn{2}{|c|}{ Meloland (1955) } \\
\hline & $\underset{4-8}{\text { November }}$ & $\underset{9-10}{\text { November }}$ & $\underset{17-29}{\text { November }}$ & $\underset{15-20}{\text { March }}$ & $\underset{16-17}{\text { May }}$ \\
\hline $8 \ldots \ldots \ldots \ldots \ldots \ldots \ldots \ldots$ & .. & . & ... & . & $2^{*}$ \\
\hline $9 \ldots \ldots \ldots \ldots \ldots \ldots \ldots \ldots \ldots \ldots \ldots \ldots \ldots \ldots \ldots$ & .. & .. & .. & . & 19 \\
\hline $10 \ldots \ldots \ldots \ldots \ldots \ldots \ldots \ldots \ldots \ldots \ldots \ldots \ldots \ldots \ldots$ & . & . & .. & . & 10 \\
\hline $11 \ldots \ldots \ldots \ldots \ldots \ldots \ldots \ldots \ldots \ldots \ldots \ldots \ldots \ldots \ldots$ & . & . & . & .. & 1 \\
\hline $12 \ldots \ldots \ldots \ldots \ldots \ldots \ldots \ldots \ldots \ldots \ldots \ldots \ldots \ldots \ldots$ & . & . & . & .. & . \\
\hline $13 \ldots \ldots \ldots \ldots \ldots \ldots \ldots \ldots \ldots \ldots \ldots \ldots \ldots \ldots \ldots$ & . & 6 & . & . & . \\
\hline $14 \ldots \ldots \ldots \ldots \ldots \ldots \ldots \ldots \ldots \ldots \ldots \ldots$ & . & 13 & . & 6 & .. \\
\hline $15 \ldots \ldots \ldots \ldots \ldots \ldots \ldots \ldots \ldots \ldots \ldots \ldots \ldots \ldots \ldots$ & . & 7 & . & 12 & .. \\
\hline $16 \ldots \ldots \ldots \ldots \ldots \ldots \ldots \ldots \ldots \ldots \ldots$ & 1 & 1 & . & 11 & .. \\
\hline $17 \ldots \ldots \ldots \ldots \ldots \ldots \ldots \ldots \ldots \ldots \ldots \ldots$ & 1 & 1 & . & 6 & .. \\
\hline $18 \ldots \ldots \ldots \ldots \ldots \ldots \ldots \ldots \ldots \ldots \ldots \ldots \ldots \ldots$ & 2 & .. & 1 & 2 & . \\
\hline 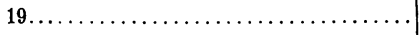 & 1 & . & 3 & 2 & .. \\
\hline 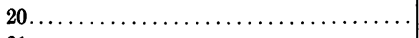 & . & . & 3 & .. & .. \\
\hline 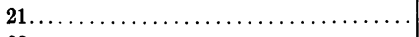 & 1 & . & 4 & . & . \\
\hline 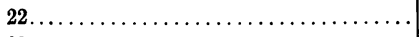 & .. & . & 4 & .. & . \\
\hline 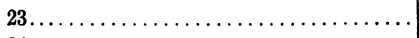 & .. & . & 2 & . & . \\
\hline 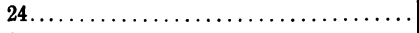 & . & . & . & . & . \\
\hline 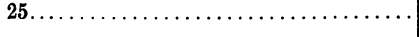 & . & . & 1 & . & . \\
\hline Average.... & 18.2 & 14.2 & 21.4 & 15.8 & 9.3 \\
\hline
\end{tabular}

* Number of individuals matured during this period. 
Nymphs born in mid-March took an average of 15.8 days to mature. The aphid was a very severe pest at that time. By mid-May, the severity of the pest had dropped off a bit, even though development was now more rapid than it had been in March.

Spotted alfalfa aphids may start to reproduce just after the last molt, or they may delay for 1 or 2 days before giving birth to their first nymphs.

TABLE 4

PRODUCTION OF NYMPHS BY 43 SPOTTED ALFALFA APHIDS MATURING

DURING THE PERIOD OF DECEMBER 1, 1954, TO FEBRUARY 7, 1955, AT RIVERSIDE CALIFORNIA. EXPERIMENT TERMINATED BY

A WIND STORM ON FEBRUARY 14, 1955

\begin{tabular}{c|c|c|c|c|c|c|c|c}
\hline \hline $\begin{array}{c}\text { Elapsed } \\
\text { days }\end{array}$ & $\begin{array}{c}\text { Young } \\
\text { produced }\end{array}$ & $\begin{array}{c}\text { Young } \\
\text { per day }\end{array}$ & $\begin{array}{c}\text { Elapsed } \\
\text { days }\end{array}$ & $\begin{array}{c}\text { Young } \\
\text { produced }\end{array}$ & $\begin{array}{c}\text { Young } \\
\text { per day }\end{array}$ & $\begin{array}{c}\text { Elapsed } \\
\text { days }\end{array}$ & $\begin{array}{c}\text { Young } \\
\text { produced }\end{array}$ & $\begin{array}{c}\text { Young } \\
\text { per day }\end{array}$ \\
\cline { 2 - 5 } 58 & 53 & 0.914 & 21 & 13 & 0.619 & 20 & 5 & 0.250 \\
21 & 38 & 1.810 & 29 & 12 & 0.414 & 28 & 5 & 0.179 \\
22 & 32 & 1.455 & 33 & 12 & 0.364 & 7 & 4 & 0.571 \\
33 & 30 & 0.909 & 15 & 11 & 0.733 & 7 & 3 & 0.429 \\
29 & 29 & 1.000 & 25 & 11 & 0.440 & 7 & 3 & 0.429 \\
25 & 28 & 1.120 & 6 & 10 & 1.667 & 13 & 3 & 0.231 \\
21 & 21 & 1.000 & 9 & 9 & 1.000 & 9 & 2 & 0.222 \\
16 & 19 & 1.187 & 5 & 7 & 1.400 & 13 & 2 & 0.154 \\
19 & 19 & 1.000 & 13 & 7 & 0.538 & 17 & 1 & 0.059 \\
19 & 19 & 1.000 & 8 & 6 & 0.750 & 6 & 0 & 0 \\
33 & 16 & 0.485 & 11 & 6 & 0.545 & 8 & 0 & 0 \\
33 & 16 & 0.485 & 12 & 6 & 0.500 & 9 & 0 & 0 \\
5 & 15 & 3.000 & 15 & 6 & 0.400 & 9 & 0 & 0 \\
41 & 15 & 0.366 & 6 & 5 & 0.833 & 9 & 0 & 0 \\
& & & & & & 13 & 0 & 0 \\
Average.. &.. & $\ldots .$. &.. &. & $\ldots .$. & 17.6 & 11.6 & 0.658 \\
\hline
\end{tabular}

Young may be well developed before the final molt, but we have never seen any born to last-instar nymphs. To obtain recently molted adults for data on production of young, 2 fully grown nymphs were placed in each of 22 cages and checked at short intervals. As soon as one had molted, the other was removed. Young were counted and removed at intervals until the death or disappearance of the adult. The adults that simply disappeared formed the most difficult part of the study. Of the 44 insects used in the spring experiments, 3 were found dead (2 from Empusa fungus), and 3 were seen to jump from the alfalfa plants while their cages were removed for checking. The rest simply disappeared. Very probably some of these died and were lost, and others jumped off their host plants while the cages were being removed or replaced. The spotted alfalfa aphid jumps quite freely when disturbed. Results of these tests are shown in tables 4, 5, and 6. The 43 aphids tested during the winter (table 4) produced young at a quite low rate. Probably the actual field production per female was higher than that shown here, but the rate of reproduction shown should be relatively accurate.

The highest total production was shown in the tests that began March 15 (table 5). Average mean temperature for this area from March 15 to April 20 was $67.4^{\circ} \mathrm{F}$. Rate of reproduction shown is not particularly high for an aphid, but was high enough to make the spotted alfalfa aphid a severe pest at that time. 
Table 5

PRODUCTION OF NYMPHS BY SPOTTED ALFALFA APHIDS MATURING MARCH 15 TO 19, 1955, AT MELOLÁND, CALIFORNIA

\begin{tabular}{|c|c|c|c|c|c|}
\hline \multirow{2}{*}{ Winged or apterous } & \multicolumn{2}{|c|}{ Dates } & \multirow{2}{*}{$\begin{array}{c}\text { Elapsed } \\
\text { days }\end{array}$} & \multirow{2}{*}{$\begin{array}{c}\text { Total } \\
\text { young }\end{array}$} & \multirow{2}{*}{$\begin{array}{l}\text { Young } \\
\text { per day }\end{array}$} \\
\hline & Molted & Died (?) & & & \\
\hline A. . & Mar. 15 & Apr. 15 & 31 & 114 & 3.677 \\
\hline A... & Mar. 18 & Apr. 20 & 33 & 113 & 3.424 \\
\hline$\ldots \ldots \ldots \ldots \ldots \ldots \ldots \ldots \ldots \ldots$ & Mar. 19 & Apr. 19 & 31 & 90 & 2.903 \\
\hline $\mathbf{W} \ldots \ldots \ldots \ldots$ & Mar. 15 & Apr. 13 & 29 & 82 & 2.828 \\
\hline $\mathbf{W} \ldots \ldots \ldots$ & Mar. 15 & Apr. 20 & 36 & 79 & 2.194 \\
\hline $\mathbf{W} \ldots$ & Mar. 15 & Apr. 20 & 36 & 68 & 1.889 \\
\hline A... & Mar. 15 & Apr. 8 & 24 & 67 & 2.792 \\
\hline 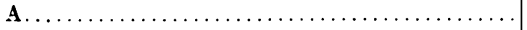 & Mar. 15 & Apr. 7 & 23 & 52 & 2.261 \\
\hline A......... & Mar. 19 & Apr. 6 & 18 & 51 & 2.833 \\
\hline $\mathbf{W} \ldots \ldots \ldots$ & Mar. 15 & Apr. 3 & 19 & 50 & 2.632 \\
\hline $\mathbf{W} \ldots$ & Mar. 17 & Apr. 13 & 27 & 44 & 1.630 \\
\hline A... & Mar. 15 & Apr. 4 & 20 & 43 & 2.150 \\
\hline A.... & Mar. 17 & Mar. 29 & 12 & 32 & 2.667 \\
\hline $\mathbf{W} \ldots$ & Mar. 15 & Mar. 30 & 15 & 28 & 1.867 \\
\hline W.. & Mar. 15 & Mar. 25 & 10 & 21 & 2.100 \\
\hline W.. & Mar. 17 & Mar. 30 & 13 & 18 & 1.385 \\
\hline A... & Mar. 15 & Mar. 25 & 10 & 13 & 1.300 \\
\hline$\ldots \ldots \ldots \ldots \ldots \ldots$ & Mar. 15 & Mar. 30 & 15 & 12 & 0.800 \\
\hline$\ldots \ldots \ldots \ldots \ldots$ & Mar. 15 & Mar. 18 & 3 & 4 & 1.333 \\
\hline$\ldots \ldots \ldots \ldots \ldots \ldots \ldots \ldots \ldots \ldots$ & Mar. 17 & Mar. 18 & 1 & 1 & 1.000 \\
\hline$\cdots \cdots \cdots \cdots \cdots \cdots \cdots$ & Mar. 17. & Mar. 21 & 4 & 1 & 0.250 \\
\hline 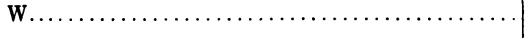 & Mar. 15 & Mar. 19 & 4 & 0 & 0.000 \\
\hline Average $\ldots \ldots \ldots \ldots \ldots \ldots \ldots \ldots \ldots \ldots \ldots \ldots \ldots \ldots \ldots$ & $\ldots \ldots$ & $\ldots \ldots \cdots$ & 18.8 & 44.7 & 2.374 \\
\hline
\end{tabular}

TABLE 6

PRODUCTION OF NYMPHS BY SPOTTED ALFALFA APHIDS MATURING MAY 16 TO 18, 1955, AT MELOLAND, CALIFORNIA

\begin{tabular}{|c|c|c|c|c|c|}
\hline \multirow{2}{*}{ Winged or apterous } & \multicolumn{2}{|c|}{ Dates } & \multirow{2}{*}{$\begin{array}{c}\text { Elapsed } \\
\text { days }\end{array}$} & \multirow{2}{*}{$\begin{array}{c}\text { Total } \\
\text { young }\end{array}$} & \multirow{2}{*}{$\begin{array}{l}\text { Young } \\
\text { per day }\end{array}$} \\
\hline & Molted & Died (?) & & & \\
\hline 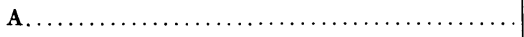 & May 16 & June 5 & 20 & 81 & 4.050 \\
\hline 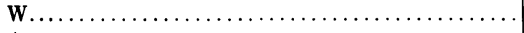 & May 17 & June 4 & 18 & 63 & 3.500 \\
\hline A. . . . & May 18 & June 3 & 16 & 61 & 3.812 \\
\hline A........ & May 17 & June 1 & 15 & 59 & 3.933 \\
\hline A... & May 16 & June 5 & 20 & 59 & 2.950 \\
\hline $\mathbf{W} \ldots$ & May 18 & June 9 & 22 & 49 & 2.450 \\
\hline W... & May 18 & June 5 & 18 & 35 & 1.944 \\
\hline A... & May 17 & June 2 & 16 & 27 & 1.687 \\
\hline $\mathbf{A} \ldots \ldots \ldots$ & May 16 & May 24 & 8 & 27 & 3.375 \\
\hline A.......... & May 17 & May 26 & 9 & 24 & 2.667 \\
\hline $\mathbf{A} \ldots \ldots \ldots$ & May 17 & May 23 & 6 & 17 & 2.833 \\
\hline $\mathbf{A} \ldots \ldots \ldots \ldots$ & May 16 & May 22 & 6 & 13 & 2.167 \\
\hline $\mathbf{A} \ldots \ldots \ldots \ldots$ & May 17 & May 20 & 3 & 7 & 2.333 \\
\hline $\mathbf{A} \ldots \ldots \ldots \ldots$ & May 16 & May 19 & 3 & 5 & 1.667 \\
\hline $\mathbf{A} \ldots \ldots \ldots \ldots$ & May 17 & May 19 & 2 & 4 & 2.000 \\
\hline $\mathbf{A} \ldots \ldots \ldots \ldots$ & May 18 & May 20 & 2 & 3 & 1.500 \\
\hline 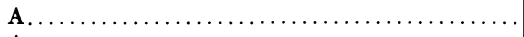 & May 17 & May 23 & 6 & 3 & 0.500 \\
\hline 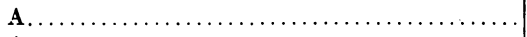 & May 16 & May 18 & 2 & 3 & 1.500 \\
\hline$\ldots \ldots \ldots \ldots \ldots \ldots \ldots \ldots \ldots \ldots \ldots \ldots$ & May 18 & May 19 & 1 & 2 & 2.000 \\
\hline .................. & May 17 & May 18 & 1 & 2 & 2.000 \\
\hline $\mathbf{A} \ldots \ldots \ldots \ldots$ & May 17 & May 18 & 1 & 2 & 2.000 \\
\hline A............ & May 17 & May 18 & 1 & 0 & 0.000 \\
\hline Average......... & $\ldots \ldots+$ & $\ldots \ldots \ldots$ & 8.9 & 24.8 & 2.786 \\
\hline
\end{tabular}


Table 6 shows records of reproduction by nymphs maturing just after mid-May. While the rate of reproduction was higher than in March, the average number of young per female was down and no individuals produced so many as did some in March and early April. Average mean temperatures during the period of May 16 to June 6 were $79.1^{\circ} \mathrm{F}$. The spotted alfalfa aphid was still reproducing well at this time and at least a good part of the cause of lower populations found then must have been predators.

\section{POPULATIONS}

As explained in the section titled, "Study Methods," a series of sampling stations was set up in the Imperial Valley to study the spread of the spotted alfalfa aphid from the apparent point of introduction at Orita siding. The stations were arranged roughly in two lines running north to south and east to west to transect the point of introduction, plus a rough circle around the south, west, and north sides of the valley. Orita siding is well to the east edge of the oval valley, so that the north to south line of the transect provided a line near its eastern edge.

The first samples were taken June 30 to July 2, 1954. Stations were sampled at weekly intervals through July and at greater intervals through the balance of the summer, the fall, and the winter. Intervals between samplings were determined by the rate of population change.

\section{THE INITIAL SURGE}

The original purpose of the study was to measure the spread of a newly introduced pest over a relatively uniform area: the alfalfa fields of this flat Imperial Valley. The sampling stations were located with this in mind. In addition to a sample of the spotted alfalfa aphid population in each field, a sample was taken of predators that might be expected to react strongly to aphid populations and, for comparison, of predators that probably would react weakly or not at all to aphids. The height of the alfalfa was measured in each field at each sampling.

It is difficult to summarize insect data from a series of alfalfa fields. A field may be used for pasture, for hay, or for seed production. Fields are cut at different heights and ages while some fields grow more rapidly than others. Each grower tries to stagger cutting dates in order to use harvesting machinery efficiently. The data from the samples taken during the first month and a half were divided into 6 categories. These were: heavily infested, newly infested, and noninfested hay fields; and heavily infested, newly infested, and noninfested seed fields. There was so little pasture sampled at that time that data from it were discarded. Data in these 6 categories are shown in tables 7 to 12 . So that comparisons might be readily made, data from the original counts of aphids on 20 stems and predators in 10 sweeps were converted to populations per acre by the method explained in the section titled "Methods." Factors used were:

Number aphids on 20 stems $\times 91,939=$ Number aphids/acre

Number ladybirds in 10 sweeps $\times 6,050=$ Number ladybirds/acre

Number Orius in 10 sweeps $\times 2,028=$ Number Orius $/$ acre

Quite arbitrarily, the factor for Orius $(2,028)$ was used for all predators listed except the ladybirds. 
The most strikingly obvious fact shown by these tables (7 to 12) is that the aphid populations in fields classified as "heavily infested hay" were much the highest. This may be chiefly explained by the fact that particularly at the start of the study most of these hay fields had not been treated by any insecticide. It also appears probable that the appearance of the

TABLE 7

AVERAGE POPULATIONS OF SPOTTED ALFALFA APHIDS (S.A.A.) AND OF VARIOUS PREDATORS IN HEAVILY INFESTED ALFALFA HAY FIELDS IN IMPERIAL VALLEY, CALIFORNIA. DATA GIVEN AS PER ACRE, 1954

\begin{tabular}{|c|c|c|c|c|c|c|c|}
\hline & \multicolumn{7}{|c|}{ Dates } \\
\hline & July 1 & July 8 & July 15 & July 22 & July 29 & Aug. 5 & Aug. 19 \\
\hline Height alfalfa (inches). & 14.3 & 12.5 & 7.3 & 8.5 & 12.7 & 11.2 & 9.0 \\
\hline S. A. A... & $146,091,000$ & $100,857,000$ & $38,063,000$ & $12,320,000$ & $3,034,000$ & 28,000 & 0 \\
\hline Coccinellid L. and P.... & 675,180 & 40,535 & 157,300 & 4,235 & 18,755 & 1,210 & $\mathbf{0}$ \\
\hline Coccinellid adults.... & 53,845 & 44,165 & 15,125 & 7,260 & 15,125 & 29,040 & 3,630 \\
\hline Syrphids. & 3,042 & 0 & $\mathbf{0}$ & 0 & 0 & 203 & 0 \\
\hline Green lacewings. . & 3,650 & 1,217 & 1,014 & 405 & 203 & $\mathbf{0}$ & $\mathbf{0}$ \\
\hline Orius.......... & 40,763 & 9,126 & 16,630 & 5,070 & 8,720 & 4,664 & 3,448 \\
\hline Geocoris.. & 3,245 & 7,706 & 3,042 & 3,245 & 10,748 & 21,700 & 10,343 \\
\hline Nabis..... & 3,042 & 3,650 & 1,014 & 203 & 4,056 & 608 & 811 \\
\hline Collops............ & $\ldots \ldots \ldots$ & $\ldots \ldots$ & $\ldots \ldots \ldots$ & 2,231 & 3,448 & 5,070 & 4,664 \\
\hline
\end{tabular}

spotted alfalfa aphid caught the ladybirds at a low ebb and that these predators were slow to increase their numbers to take advantage of the new supply of food. Possibly the ladybirds had to develop a strain that liked the new aphid, or one that looked on the lower parts of the stems for aphids, rather than near the tops. All the seed fields were treated regularly for Lygus bugs, mostly with a dust containing 15 per cent toxaphene, 5 per

TABLE 8

AVERAGE POPULATIONS OF SPOTTED ALFALFA APHID AND OF VARIOUS PREDATORS IN NEWLY (LIGHTLY) INFESTED ALFALFA HAY FIELDS IN IMPERIAL VALLEY, CALIFORNIA. DATA GIVEN AS PER ACRE, 1954

\begin{tabular}{|c|c|c|c|c|c|c|c|}
\hline & \multicolumn{7}{|c|}{ Dates } \\
\hline & July 1 & July 8 & July 15 & July 22 & July 29 & Aug. 5 & Aug. 19 \\
\hline Height alfalfa (inches). & 16.0 & 12.1 & 8.7 & 7.9 & 10.3 & 14.5 & 9.4 \\
\hline S. A. A.. & $1,066,000$ & $3,006,000$ & $13,598,000$ & $4,653,000$ & $1,296,000$ & $1,103,000$ & 18,000 \\
\hline Coccinellid L. and P. & $\mathbf{0}$ & 605 & 5,445 & 1,815 & 0 & 605 & 0 \\
\hline Coccinellid adults..... & 6,680 & 2,420 & 1,210 & 2,420 & 3,025 & 5,445 & 605 \\
\hline Syrphids............. & 0 & 203 & 0 & 0 & 0 & 0 & 0 \\
\hline Green lacewings........ & 203 & 0 & 203 & 0 & 0 & 0 & 0 \\
\hline Orius................ & 22,511 & 10,343 & 20,282 & 4,867 & 4,462 & 6,287 & 5,273 \\
\hline Geocoris . . . . . & 16,630 & 7,098 & 10,343 & 9,532 & 6,692 & 24,539 & 13,385 \\
\hline Nabis................ & 1,420 & 3,042 & 811 & 1,217 & 1,622 & 3,245 & 2,434 \\
\hline Collops.............. & $\ldots \ldots \ldots$ & $\ldots \ldots$ & $\ldots \ldots \ldots$ & 2,636 & 2,636 & 5,475 & 2,839 \\
\hline
\end{tabular}


cent DDT, and 40 per cent sulfur. This dust was applied to seed fields without regard to the spotted alfalfa aphid, but happened to be rather effective in controlling it. It is also possible that the fresh growth found in hay fields is more favorable to the spotted alfalfa aphid than are the mature plants found in seed fields after the bloom starts.

TABLE 9

AVERAGE POPULATIONS OF VARIOUS PREDATORS IN ALFALFA HAY FIELDS NOT INFESTED BY SPOTTED APHID, IMPERIAL VALLEY, CALIFORNIA. DATA GIVEN AS PER ACRE, 1954

\begin{tabular}{|c|c|c|c|c|c|c|c|}
\hline & \multicolumn{7}{|c|}{ Dates } \\
\hline & July 1 & July 8 & July 15 & July 22 & July 29 & Aug. 5 & Aug. 19 \\
\hline Height alfalfa (inches). & 12.1 & 11.5 & 9.8 & 12.0 & 17.5 & 9.1 & 11.5 \\
\hline S. A. A... & 0 & 0 & 0 & 0 & 0 & $\mathbf{0}$ & $\mathbf{0}$ \\
\hline Coccinellid L. and P... & 0 & 0 & $\mathbf{0}$ & 1,210 & 0 & $\mathbf{0}$ & $\mathbf{0}$ \\
\hline Coccinellid adults..... & 0 & 1,210 & 2,420 & 0 & 1,210 & 1,210 & $\mathbf{0}$ \\
\hline Syrphids.......... & 0 & $\mathbf{0}$ & $\mathbf{0}$ & 0 & 0 & 203 & $\mathbf{0}$ \\
\hline Green lacewings. . & 2,028 & 0 & 0 & 406 & 0 & 0 & 0 \\
\hline Orius............ & 6,084 & 1,014 & 7,706 & 6,084 & 7,504 & 8,518 & 3,042 \\
\hline Geocoris.. & 0 & 1,420 & 11,762 & 6,490 & 4,056 & 17,035 & 4,867 \\
\hline Nabis...... & 0 & 1,420 & 0 & 1,420 & 406 & 2,028 & 3,448 \\
\hline Collops............... & $\ldots \ldots$ & $\ldots \ldots$ & $\ldots \ldots$ & 9,532 & 1,420 & 3,853 & 2,231 \\
\hline
\end{tabular}

The second obvious point is that the spotted alfalfa aphid population was either at its peak or had just started down at the time this study was begun. The first counts in the "heavily infested" fields were the highest

TABLE 10

AVERAGE POPULATIONS OF SPOTTED ALFALFA APHID AND OF VARIOUS PREDATORS IN HEAVILY INFESTED ALFALFA SEED FIELDS IN IMPERIAL VALLEY, CALIFORNIA. DATA

GIVEN AS PER ACRE, 1954

\begin{tabular}{|c|c|c|c|c|c|c|c|}
\hline & \multicolumn{7}{|c|}{ Dates } \\
\hline & July 1 & July 8 & July 15 & July 22 & July 29 & Aug. 5 & Aug. 19 \\
\hline Height alfalfa (inches). & 17.6 & 17.8 & 20.9 & 19.0 & 20.6 & 18.5 & 17.3 \\
\hline S. A. A.... & $9,185,000$ & $25,292,000$ & $18,323,000$ & $1,462,000$ & 74,000 & 74,000 & 0 \\
\hline Coccinellid L. and P... & 3,025 & 0 & 1,210 & 4,840 & $\mathbf{0}$ & 0 & $\mathbf{0}$ \\
\hline Coccinellid Adults..... & 12,705 & 3,025 & 14,520 & 3,025 & 3,025 & 1,210 & 0 \\
\hline Syrphids............ & $\mathbf{0}$ & 0 & 0 & 406 & 0 & 0 & 0 \\
\hline Green lacewings....... & $\mathbf{0}$ & 203 & 406 & 406 & $\mathbf{0}$ & 406 & 406 \\
\hline Orius................ & 52,120 & 4,867 & 33,868 & 8,112 & 11,154 & 3,042 & 1,217 \\
\hline Geocoris.............. & 9,126 & 608 & 203 & 2,636 & 5,070 & 7,706 & 203 \\
\hline Nabis.................. & 4,259 & 1,014 & 0 & 406 & 1,014 & 608 & 0 \\
\hline Collops............ & $\ldots \ldots$ & ........ & n....... & 1,622 & 6,490 & 10,343 & 5,070 \\
\hline
\end{tabular}

obtained that summer. The highest count obtained in an individual field (except for one in the spring of 1955) was made at the first check. It was 8,000 for 20 stems, which equals 400 per stem or 735 million per acre.

The fields classified as heavily infested were generally within a few miles of the presumed point of introduction at Orita siding. South, west, and 
northwest of these heavily infested fields were the newly infested fields that gave low counts when the study was begun. Some fields not found to be infested at the first count were found infested in subsequent checks. The aphid populations in the fields infested later did not reach the peaks shown by the fields nearer Orita. The later infested fields reached their peak at the July 15 counts, 2 weeks after the work started. After this date, they, too, showed lower aphid populations each week, although in general they did not drop as rapidly as did those fields infested earlier.

These population decreases could have been caused either by biological factors, such as predators, or by climatic factors. The most conspicuous climatic factor in July in the Imperial Valley was the very high temperature.

\section{PREDATOR RELATIONSHIPS}

No parasites were seen attacking the spotted alfalfa aphid, and none were reported by Tuttle and Butler (1954). The original intention was to count parasitized aphids, but none were found. Counts were made of the larger predatory insects found in the alfalfa fields. Of these, the ladybird beetles, the green lacewings, and the syrphids were obviously attracted to the spotted alfalfa aphids. Rarely, Orius, Geocoris, and Nabis were seen feeding on spotted alfalfa aphids, and once a predatory thrips was seen eating a very small aphid. The question we are interested in is which predators attack the spotted alfalfa aphid and how effective are they? We cannot measure effectiveness directly. We can only discover which predator populations vary with the spotted alfalfa aphid populations, and which vary independently. A predator population that varies with the spotted alfalfa aphid population may do so because the species feeds directly on the aphids, or because it feeds on some insect that does eat aphids. Thus, an insect species that eats ladybird eggs might increase in the presence of a large aphid population because of the many eggs present, even though it never ate an aphid.

Tables 13 to 16 were prepared to make evident the changes in predator

TABLE 11

AVERAGE POPULATIONS OF SPOTTED ALFALFA APHIDS AND OF

VARIOUS PREDATORS IN NEWLY (LIGHTLY) INFESTED

ALFALFA SEED FIELDS IN IMPERIAL VALLEY,

CALIFORNIA. DATA GIVEN AS

PER ACRE, 1954

\begin{tabular}{|c|c|c|c|c|c|c|c|}
\hline & \multicolumn{7}{|c|}{ Dates } \\
\hline & July 1 & July 8 & July 15 & July 22 . & July 29 & Aug. 5 & Aug. 19 \\
\hline Height alfalfa (inches). & 21.0 & 20.8 & 17.6 & 21.2 & 21.8 & 18.2 & 13.6 \\
\hline S. A. A.... & 92,000 & 349,000 & $2,427,000$ & 644,000 & 55,000 & 92,000 & 0 \\
\hline Coccinellid L. and P... & 3,025 & $\mathbf{0}$ & $\mathbf{0}$ & 0 & $\mathbf{0}$ & $\mathbf{0}$ & 0 \\
\hline Coccinellid adults..... & $\mathbf{0}$ & 2,420 & $\mathbf{0}$ & 0 & 0 & $\mathbf{0}$ & 0 \\
\hline Syrphids..... & $\mathbf{0}$ & $\mathbf{0}$ & $\mathbf{0}$ & $\mathbf{0}$ & $\mathbf{0}$ & $\mathbf{0}$ & 0 \\
\hline Green lacewings........ & $\mathbf{0}$ & $\mathbf{0}$ & $\mathbf{0}$ & $\mathbf{0}$ & $\mathbf{0}$ & 0 & $\mathbf{0}$ \\
\hline Orius................ & 52,728 & 8,923 & 21,902 & 3,650 & 9,329 & 2,028 & 3,650 \\
\hline Geocoris.............. & 0 & 5,678 & 13,790 & 2,028 & 6,895 & 11,357 & 4,065 \\
\hline Nabis........ & 0 & 811 & 0 & 0 & 2,028 & 0 & 406 \\
\hline Collops................ & ........ & ........ & ........ & 811 & 1,622 & 3,650 & 0 \\
\hline
\end{tabular}


populations and their relationship to spotted alfalfa aphid populations. Data in these tables were prepared by using noninfested hay or seed fields as a base. It was assumed that predator populations in these noninfested fields had not been influenced by the spotted alfalfa aphid. Average counts in the noninfested fields were subtracted from average counts in fields heavily

TABLE 12

AVERAGE POPULATIONS OF VARIOUS PREDATORS IN ALFALFA SEED FIELDS NOT INFESTED WITH SPOTTED ALFALFA APHID, IMPERIAL VALLEY, CALIFORNIA. DATA GIVEN AS PER ACRE, 1954

\begin{tabular}{|c|c|c|c|c|c|c|c|}
\hline & \multicolumn{7}{|c|}{ Dates } \\
\hline & July 1 & July 8 & July 15 & July 22 & July 29 & Aug. 5 & Aug. 19 \\
\hline Height alfalfa (inches). & 16.0 & 17.6 & 20.6 & 20.6 & 20.6 & 20.6 & 12.2 \\
\hline S. A. A.... & 0 & 0 & 0 & 0 & 0 & 0 & 0 \\
\hline Coccinellid L. and P... & 0 & 1,210 & 0 & 1,210 & 0 & 0 & 0 \\
\hline Coccinellid adults.... & 1.210 & 1,210 & 0 & 3,630 & 0 & 0 & $\mathbf{0}$ \\
\hline Syrphids............ & 9 & 0 & 0 & 0 & $\mathbf{0}$ & $\mathbf{0}$ & 0 \\
\hline Green lacewings. . & 2,028 & 406 & 406 & 0 & 0 & 406 & 0 \\
\hline Orius............ & 32,448 & 12,979 & 49,889 & 12,168 & 16,224 & 12,979 & 3,650 \\
\hline Geocoris.. & 3,042 & 0 & 1,217 & 406 & 406 & 1,622 & 406 \\
\hline Nabis.......... & 0 & $\mathbf{0}$ & 0 & 0 & 0 & $\mathbf{0}$ & 1,217 \\
\hline Collops.......... & $\ldots \ldots$ & $\ldots \ldots$ & $\ldots \ldots$ & 6,895 & 811 & 7,201 & 5,273 \\
\hline
\end{tabular}

or newly infested by spotted alfalfa aphids to give a remainder indicating the changes based on the presence of spotted alfalfa aphid populations. Coccinellid populations appear to be positively correlated with the aphid populations except in lightly infested seed fields (table 16). Populations of ladybird larvae and pupae (mostly larvae) followed the aphid populations very closely. Adult ladybird populations lagged a bit, as is to be

TABLE 13

AVERAGE EXCESS (OR DEFICIENCY) OF VARIOUS PREDATORS IN ALFALFA HAY FIELDS HEAVILY INFESTED WITH SPOTTED ALFALFA APHIDS AS COMPARED TO NONINFESTED

ALFLAFA HAY FIELDS, IMPERIAL VALLEY, CALIFORNIA. DATA SHOWN AS PER ACRE, 1954

\begin{tabular}{|c|c|c|c|c|c|c|c|}
\hline & \multicolumn{7}{|c|}{ Dates } \\
\hline & July 1 & July 8 & July 15 & July 22 & July 29 & Aug. 5 & Aug. 19 \\
\hline S. A. A. & $146,091,000$ & $100,857,000$ & $38,063,000$ & $12,320,000$ & $3,034,000$ & 28,000 & 0 \\
\hline Coccinellid L. and P... & 675,180 & 40,535 & 157,300 & 3,025 & 18.755 & 1,210 & 0 \\
\hline Coccinellid adults..... & 53,845 & 42,955 & 12,705 & 7,260 & 13,915 & 27,830 & 3,630 \\
\hline Syrphids......... & 3,042 & 0 & $\mathbf{0}$ & 0 & 0 & 0 & 0 \\
\hline Green lacewings. . & 1,622 & 1,217 & 1,014 & 0 & 203 & 0 & 0 \\
\hline Orius............. & 34,679 & 8,112 & 8,924 & $-1,014$ & 1,216 & $-\$, 850$ & 406 \\
\hline Geocoris.. & 3,245 & 6,286 & $-10,748$ & $-3,245$ & 6,692 & 4,665 & 5,467 \\
\hline Nabis...... & 3,042 & 2,230 & 1,014 & $-1,217$ & 0 & $-1,420$ & $-8,687$ \\
\hline Collops....... & $\ldots \ldots \ldots$ & $\ldots \ldots$ & $\ldots \ldots \ldots$ & $-7,301$ & 2,028 & 1,218 & 2,433 \\
\hline
\end{tabular}


expected. The most heavily infested hay fields (table 13) showed much the greatest increase in ladybird populations and the most conspicuous lag. On August 5, the counts indicated more ladybirds than aphids in these fields. It is obvious that ladybirds reduced the aphid populations appreciably in certain fields. The data indicate it and their work was observed. It was also

TABLE 14

AVERAGE EXCESS (OR DEFICIENCY) OF VARIOUS PREDATORS IN ALFALFA HAY FIELDS NEWLY (LIGHTLY) INFESTED WITH SPOTTED ALFALFA APHIDS AS COMPARED TO NON-

INFESTED ALFALFA HAY FIELDS, IMPERIAL

VALLEY, CALIFORNIA. DATA SHOWN AS PER ACRE, 1954

\begin{tabular}{|c|c|c|c|c|c|c|c|}
\hline & \multicolumn{7}{|c|}{ Dates } \\
\hline & July 1 & July 8 & July 15 & July 22 & July 29 & Aug. 5 & Aug. 19 \\
\hline S. A. A.. & $1,066,000$ & $3,006,000$ & $13,598,000$ & $4,653,000$ & $1,296,000$ & $1,103,000$ & 18,000 \\
\hline Coccinellid L. and P... & 0 & 605 & 5,445 & 605 & 0 & 605 & 0 \\
\hline Coccinellid adults..... & 6,680 & 1,210 & $-1,210$ & 2,420 & 1,815 & 4,235 & 605 \\
\hline Syrphids......... & 0 & 203 & 0 & $\mathbf{0}$ & $\mathbf{0}$ & -208 & $\mathbf{0}$ \\
\hline Green lacewings. . & $-1,825$ & 0 & 203 & -406 & 0 & $\mathbf{0}$ & $\mathbf{0}$ \\
\hline Orius $\ldots \ldots \ldots \ldots$ & 16,427 & 9,329 & 12,574 & $-1,217$ & $-3,042$ & $-2,281$ & 2,231 \\
\hline Geocoris. & 10,546 & 5,678 & $-1,419$ & 3,042 & 2,636 & 7,204 & 4,664 \\
\hline Nabis.... & 1,420 & 1,622 & 811 & -203 & 1,216 & 1,217 & $-1,014$ \\
\hline Collops....... & $\ldots \ldots$ & $\ldots \ldots$ & $\ldots$ & $-6,898$ & 1,216 & 1,622 & 608 \\
\hline
\end{tabular}

TABLE 15

AVERAGE EXCESS (OR DEFICIENCY) OF VARIOUS PREDATORS IN ALFALFA SEED FIELDS HEAVILY INFESTED WITH SPOTTED ALFALFA APHIDS AS COMPARED TO NONINFESTED ALFALFA SEED FIELDS, IMPERIAL VALLEY, CALIFORNIA. DATA SHOWN AS PER ACRE, 1954

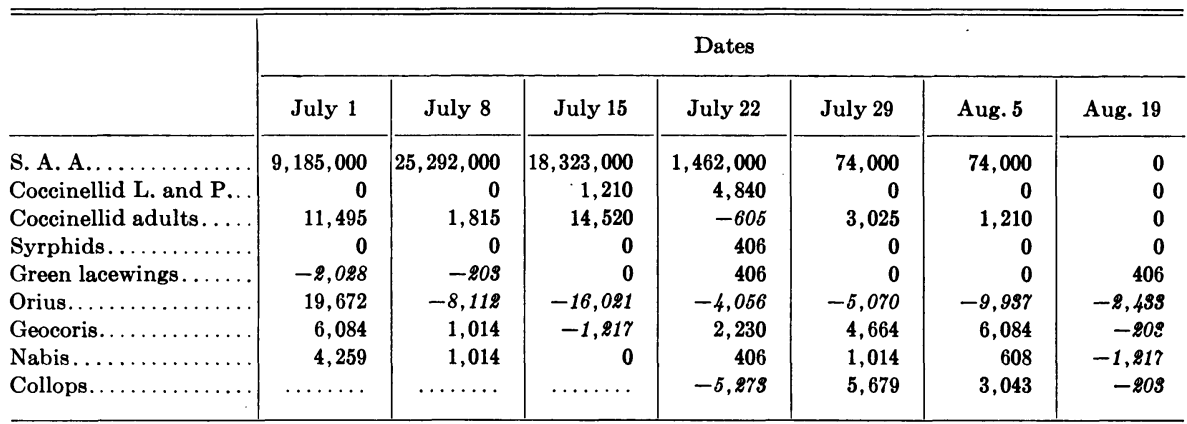

observed that during this period the ladybirds cleaned up many fields too late to save the hay crops. They were, however, quite efficient in cleaning up the stubble.

Syrphids were too rare to have any appreciable effect, or to measure. Under these conditions they were not a factor.

Green lacewings seem to have been very slightly correlated to the aphid 
TABLE 16

AVERAGE EXCESS (OR DEFICIENCY) OF VARIOUS PREDATORS IN ALFALFA SEED FIELDS NEWLY (LIGHTLY) INFESTED WITH SPOTTED ALFALFA APHIDS AS COMPARED TO NONINFESTED ALFALFA SEED FIELDS, IMPERIAL VALLEY, CALIFORNIA. DATA SHOWN AS PER ACRE, 1954

\begin{tabular}{|c|c|c|c|c|c|c|c|}
\hline & \multicolumn{7}{|c|}{ Dates } \\
\hline & July 1 & July 8 & July 15 & July 22 & July 29 & Aug. 5 & Aug. 19 \\
\hline S. A. A......... & 92,000 & 349,000 & $2,427,000$ & 644,000 & 55,000 & 92,000 & $\mathbf{0}$ \\
\hline Coccinellid L. and P... & 3,025 & $-1,210$ & 0 & $-1,210$ & 0 & 0 & 0 \\
\hline Coccinellid adults..... & $-1,210$ & 1,210 & $\mathbf{0}$ & $-\$, 680$ & 0 & 0 & 0 \\
\hline Syrphids............. & 0 & $\mathbf{0}$ & 0 & 0 & $\mathbf{0}$ & 0 & $\mathbf{0}$ \\
\hline Green lacewings. & $-2,028$ & -406 & -406 & $\mathbf{0}$ & $\mathbf{0}$ & -406 & 0 \\
\hline Orius............. & 20,280 & $-4,056$ & $-27,986$ & $-8,518$ & $-6,895$ & $-10,951$ & 0 \\
\hline Geocoris. & $-3,042$ & 5,678 & 12,573 & 1,622 & 6,489 & 9,735 & 3,650 \\
\hline Nabis.... & $\mathbf{0}$ & 811 & $\mathbf{0}$ & 0 & 2,028 & $\ldots \ldots$ & -811 \\
\hline Collops.. & $\ldots \ldots$ & $\ldots \ldots$ & $\ldots \ldots$ & $-6,084$ & 811 & $-\$, 651$ & $-5,279$ \\
\hline
\end{tabular}

populations in table 13 , but the other 3 tables show a negative correlation, so it appears that at this time, green lacewing populations were essentially independent of aphid populations. Green lacewings showed unusually low populations generally on the desert that summer, so probably a parasite or disease was keeping them down. They are general predators that are often effective against aphids.

Minute pirate bugs, Orius, showed a small positive correlation in table 13, with the highest aphid populations, but an independent (or negative tendency in the other tables. Since they are general predators with a preference for thrips, it appears that they were essentially independent of the aphid populations and are not a factor in controlling the spotted alfalfa aphid.

Big-eyed bugs, Geocoris spp., showed a slight positive correlation with aphid populations. It is not marked, however, and if it is a predatory factor it may be mostly secondary.

Damsel bugs, Nabis, showed population trends that are independent to slightly correlated with the aphids. Their numbers were relatively low, and they appeared to be of minor importance.

Collops beetles were not sampled until July 22. They appear to have varied independently.

\section{THE EBB}

As stated above, it was assumed when the study was begun that this pest would spread uninterruptedly over the entire Imperial Valley from the original point of introduction. At that time this spread seemed well on its way. As the aphid became abundant in fields increasingly distant from the focal point, it was possible to measure the spread of the aphid population, and the subsequent increase of ladybirds in these fields. It soon became apparent that although the aphid was still spreading, the fields infested later were not showing such high populations as had those infested earlier. Populations also became lower in the fields near the point of original introduction. By the end of July, aphid populations were strikingly lower in almost all 


\begin{tabular}{|c|c|c|c|c|c|c|c|c|}
\hline $\begin{array}{l}\text { 圆 } \\
\text { 号 } \\
\text { o } \\
\text { O }\end{array}$ & & 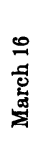 & 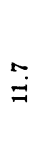 & 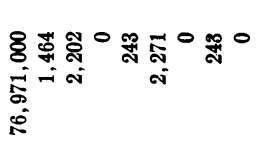 & & $\stackrel{\Xi}{\Xi}$ & $\underset{\mathscr{\varpi}}{\ddot{n}}$ & 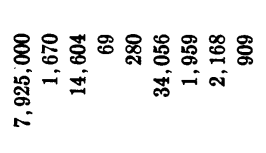 \\
\hline 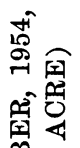 & & 密 & $\underset{\infty}{\infty}$ & 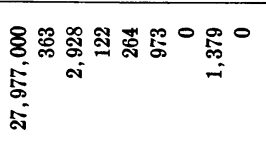 & & 窟 & $\stackrel{0}{=}$ & 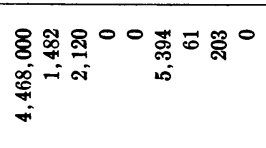 \\
\hline 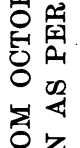 & & 窟 & & 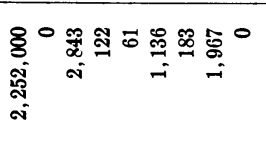 & & 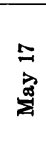 & ف몀 & 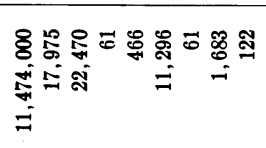 \\
\hline 崖各 & & 雍 & $\underset{\infty}{\infty}$ & 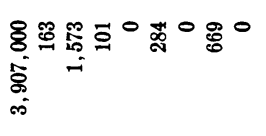 & & $\stackrel{\circ}{\stackrel{9}{m}}$ & $\stackrel{0}{\leftrightarrows}$ & 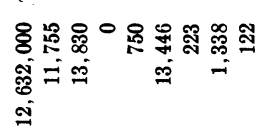 \\
\hline 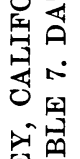 & 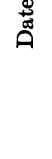 & 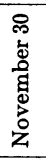 & $\stackrel{\square}{=}$ & 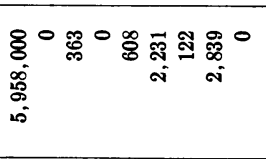 & $\stackrel{\vec{J}}{\mathrm{~J}}$ & $\stackrel{\infty}{\stackrel{m}{z}}$ & $\stackrel{4}{a}$ & 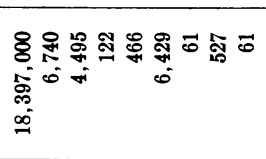 \\
\hline 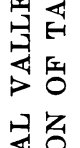 & & 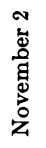 & 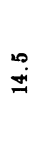 & 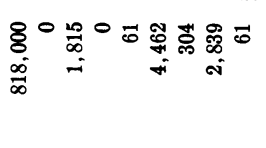 & & 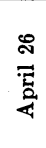 & $\vec{m}$ & 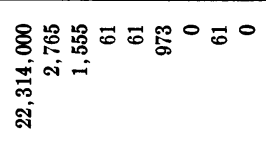 \\
\hline 锢曷 & & 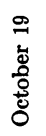 & $\stackrel{9}{\mathfrak{g}}$ & 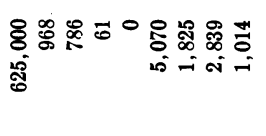 & & $\frac{\Im}{7}$ & $\stackrel{0}{9}$ & 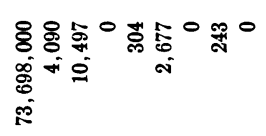 \\
\hline 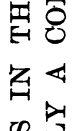 & & م & & 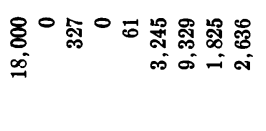 & & 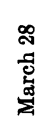 & 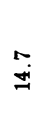 & 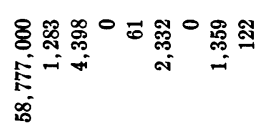 \\
\hline 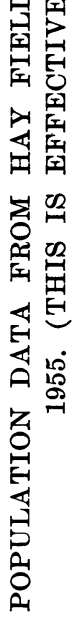 & & & 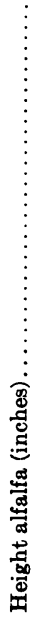 & 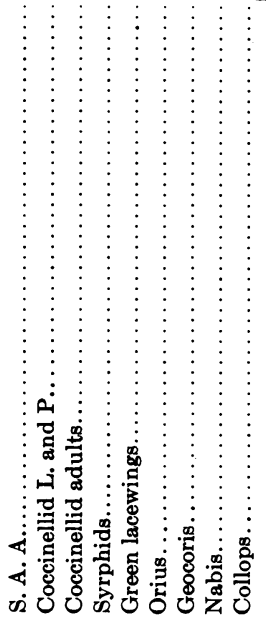 & & & 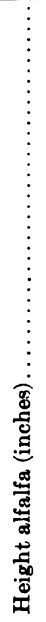 & 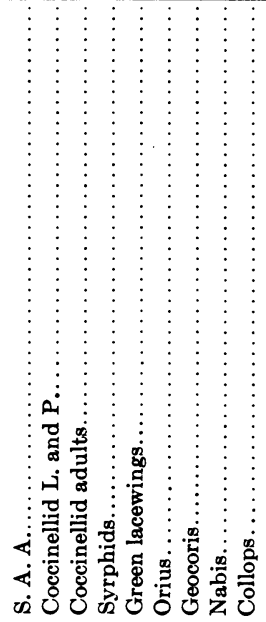 \\
\hline
\end{tabular}


the infested fields, and a week later they were almost gone. This occurred all over the valley, in fields so newly infested that no increase in predator populations could be measured, as well as in the fields first infested. It is obvious that the factor or factors responsible for this general lowering of population levels were independent of the aphid populations. The most probable factor was high temperature. Temperatures at the bases of the plants in alfalfa fields were measured and found to be within 1 to $2^{\circ} \mathrm{F}$ of shade temperatures outside the fields, although humidity was considerably higher. A maximum of $121^{\circ} \mathrm{F}$ was officially reported for El Centro one day during that period, and there were several days with maximums of $115^{\circ} \mathrm{F}$ or higher. It is probable that the predators aided in lowering the aphid populations. Under conditions unfavorable to the aphid, the continuous pressure of both general and specific predators becomes much more effective than when conditions are favorable for the aphid. As the aphid population decreases, general predators will become relatively more important since their populations do not decrease sharply with any specific host.

\section{FALL, WINTER, AND SPRING}

Spotted alfalfa aphid populations remained very low through September on the desert and when checked early in October were still low in the Imperial Valley, although they were rising in the Palo Verde and Coachella valleys.

TABLE 18

CATCHES OF HIPPODAMIA CONVERGENS GUERIN AND CYCLONEDA SANGUINEA (L.) ADULTS IN ALFALFA FIELDS IN THE IMPERIAL VALLEY, CALIFORNIA, 1954-1955

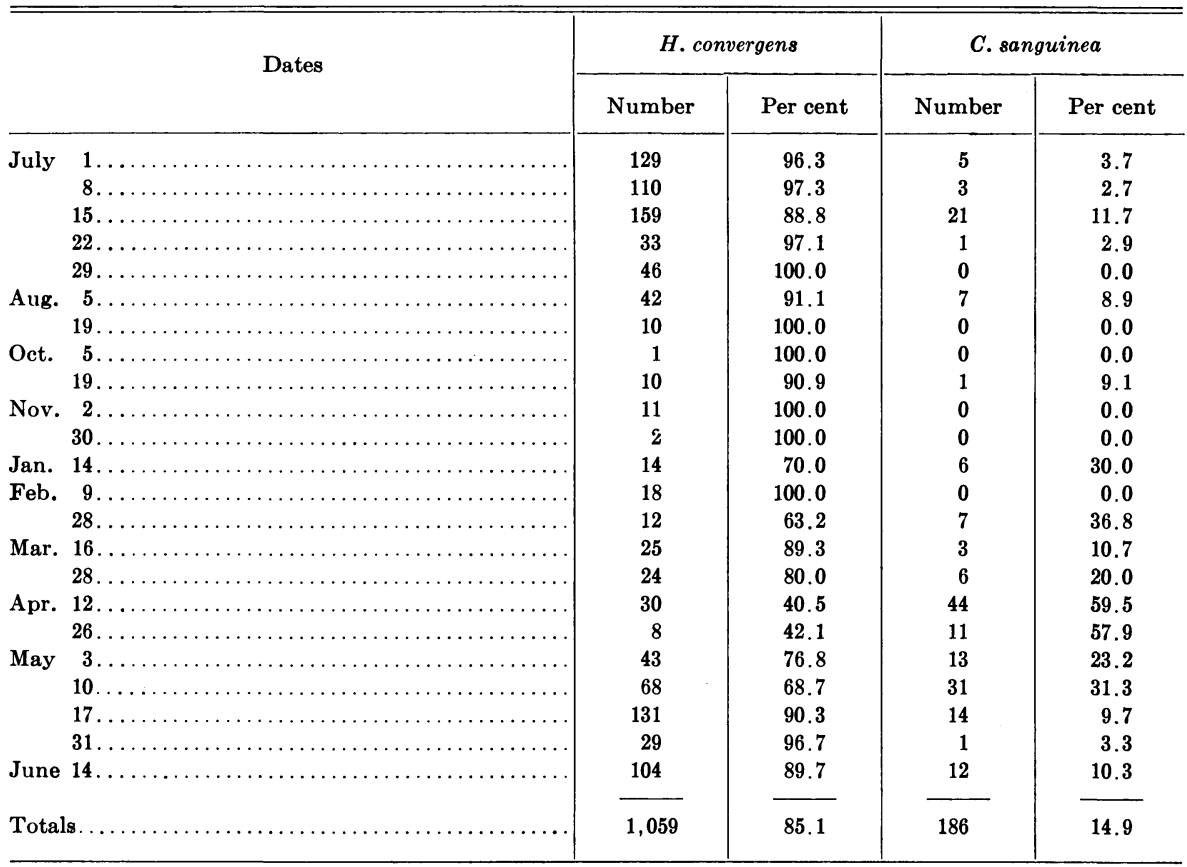


By then it was assumed that the spotted alfalfa aphid was generally distributed over the valley, and, since all the alfalfa seed fields had been harvested, the groupings used earlier were abandoned. By then they were only hay and pasture fields.

As shown in table 17, spotted alfalfa aphid populations rose slowly during

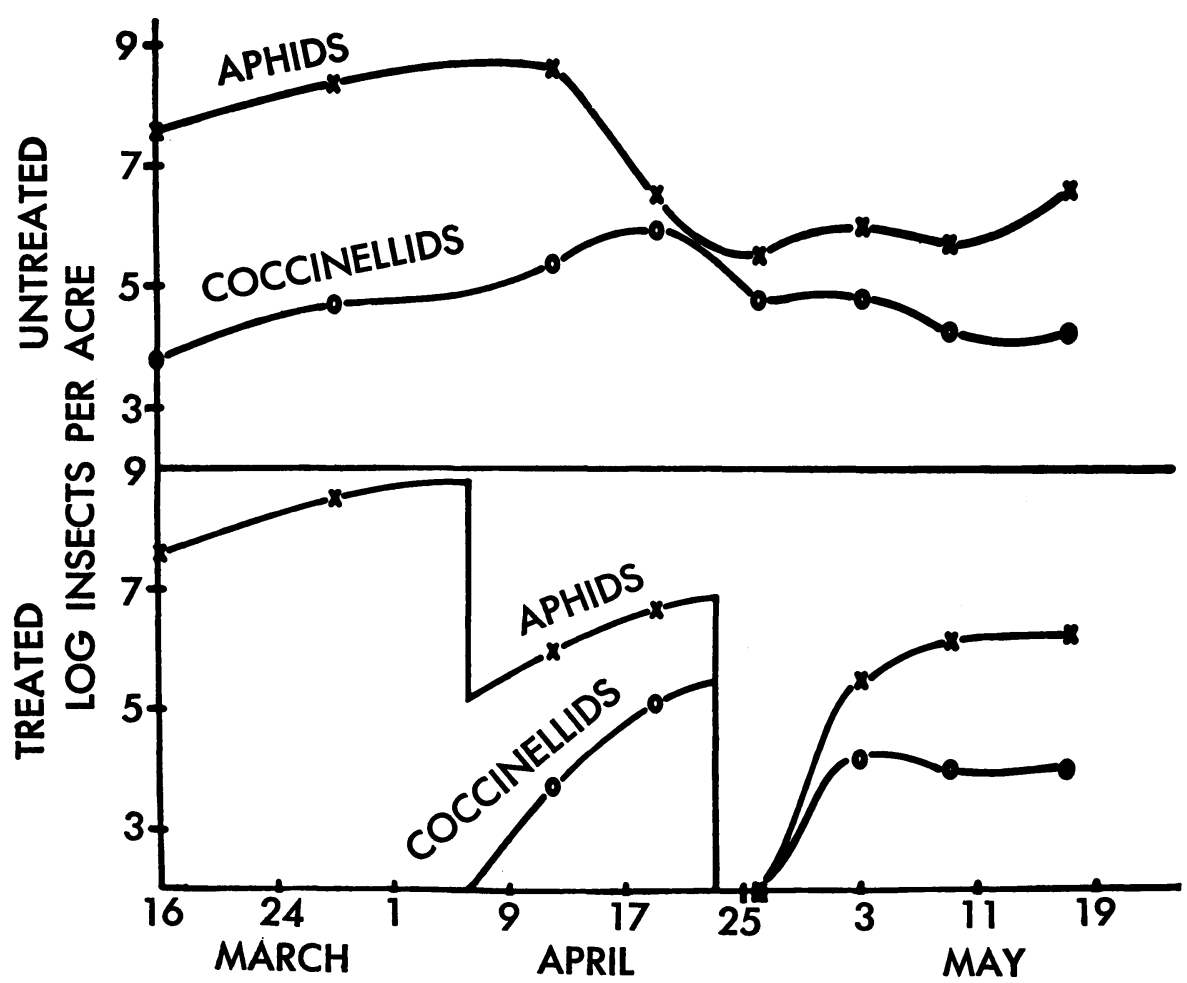

Fig. 3. Populations of spotted alfalfa aphids and of ladybird beetles in two alfalfa fields near Brawley, California. One field was treated twice, while the other was untreated.

the fall, and then dropped during the winter. They rose more rapidly in February and the first insecticide applications on hay fields were made about March 1. Average aphid counts never got as high at any time during the spring as they had been on July 1, 1954, when the work was begun. This was at least partly because of the widespread use of insecticides. By March 28, 53 per cent of the hay fields sampled had been treated. Those fields that had not been treated gave aphid counts indicating average populations of $128,715,000$ spotted alfalfa aphids per acre. The highest counts recorded for any field were made April 19 near Westmoreland. They showed populations of 600 aphids per stem, or about $1,100,000,000$ per acre. Ladybirds were still ineffective at that time. They first built up to effective numbers in a few fields about April 15, and did not become generally abundant in alfalfa fields until about 3 weeks after that.

Two species of ladybird beetle, Hippodamia convergens Guerin, and Cycloneda sanguinea (L.), were found eating the spotted alfalfa aphid in the Imperial Valley. Both seem to be present throughout the year, but the 
blood-red ladybird, C. sanguinea (L.), generally makes up an important part of the total ladybird population only in the spring. Counts are shown in table 18.

It appears that the widespread use of insecticides, chiefly parathion, to control the spotted alfalfa aphid only slightly delayed the appearance of enough ladybird beetles in the fields to make them important factors in aphid population contrel. This fact is emphasized by records from two fields shown

\section{TABLE 19}

COUNTS OF PEA APHIDS AND SPOTTED ALFALFA APHIDS MADE IN THE IMPERIAL VALLEY, CALIFORNIA, IN LATE 1954 AND

THROUGH THE SPRING OF 1955. COUNTS WERE MADE ON THE SAME STEMS

\begin{tabular}{|c|c|c|c|c|}
\hline \multirow{2}{*}{ Dates } & \multicolumn{2}{|c|}{ Pea aphid } & \multicolumn{2}{|c|}{ Spotted alfalfa aphid } \\
\hline & Number & Per cent & Number & Per cent \\
\hline Nov. 30 . & 1 & 0.010 & 9,602 & 99.990 \\
\hline Jan. $14 \ldots$ & 15 & 0.452 & 3,304 & 99.548 \\
\hline Mar. $1 \ldots$ & 150 & 1.262 & 11,738 & 98.738 \\
\hline Mar. $14 \ldots$. & 545 & 1.183 & 45,587 & 98.817 \\
\hline Mar. $28 \ldots$. & 30 & 0.094 & 31,874 & 99.906 \\
\hline Apr. $12 \ldots$ & 577 & 1.643 & 34,539 & 98.357 \\
\hline Apr. $19 \ldots \ldots$ & 770 & 1.882 & 40,132 & 98.118 \\
\hline Apr. $26 \ldots$ & 452 & 3.979 & 10,907 & 96.021 \\
\hline May $3 \ldots \ldots$ & 214 & 2.287 & 9,143 & 97.713 \\
\hline May $10 \ldots \ldots$ & 188 & 3.485 & 5,206 & 96.515 \\
\hline May $17 \ldots \ldots \ldots$ & 123 & 2.302 & 5,220 & 97.698 \\
\hline May $31 \ldots \ldots \ldots \ldots$ & 14 & 0.506 & 5,723 & 99.494 \\
\hline June $14 \ldots \ldots \ldots \ldots \ldots$ & 0 & 0 & 3,319 & 100.000 \\
\hline
\end{tabular}

in figure 3. One of these fields was treated twice while the other was untreated. The aphid populations followed very different patterns in these two fields, but by about May 9 they were very much alike. Barley and sugar beet fields were important reservoirs of ladybirds in this area. It would also appear that alfalfa fields do not act as units for ladybirds. These insects disperse so freely that the unit of ladybird population is a much larger district than the individual field. Again, it appears that ladybirds almost disappear from an alfalfa field shortly after its aphid population has been reduced to a low point. This happens whether the aphids have been cleaned out by insecticides or by the ladybirds themselves. Adult ladybirds generally fly from a clean field while those larvae that have become full fed spin up to pupate. Some of these larvae complete their development, but many of them are destroyed before they can pupate, particularly in stubble fields where there are few hiding places. Many of these spun-up and helpless larvae are eaten by other ladybirds that are still searching the field.

Green lacewings did not build up to high enough numbers to have much effect on aphid populations. They were rather high in beet fields in the early spring, but did not build up in response to the spotted alfalfa aphid populations in alfalfa. This was true despite the fact that in some years in the past they have been quite effective against the pea aphid in the same area. Their lack of effectiveness against the spotted alfalfa aphid may have to 
do with the fact that the spotted alfalfa aphid locates itself on the lower part of the alfalfa plant while the pea aphid stays near the plant's top. The pea aphid was not so prevalent in 1955 as it had been in recent springs before the spotted alfalfa aphid appeared. Possibly, the insecticides used primarily against the spotted alfalfa aphid were responsible for this change. Counts of pea aphids were made through the spring on the same stems checked for spotted alfalfa aphids. Data are shown in table 19. These show that the pea aphid was actually a very small part of the total aphid population on alfalfa at this time. Counts made from sweepings would have indicated a much higher proportion of pea aphids, since they tend to cluster at the tops of plants.

Orius was present throughout the year as was Nabis, while Geocoris and Collops nearly or completely disappeared for a while in the winter and early spring.

\section{POPULATION SUMMARY}

When found late in June, 1954, near Orita siding east of Brawley, the spotted alfalfa aphid had already increased to a damaging population in the alfalfa fields. The aphid population had already started down at the time work was begun on it July 1 . Populations continued to spread through most of July, but peaks became progressively lower. This decrease seems to have been associated with high summer temperatures and to have been assisted locally by ladybird predators.

Aphid populations began to pick up early in October, but did not get very high during the fall. Almost the only fall damage was to seedling alfalfa. Fall populations were considerably higher in the nearby Palo Verde and Coachella valleys.

The spotted alfalfa aphid increased with warmer spring weather so that the first insecticide treatments were necessary about March 1 . Treatment for this aphid was general until mid-April when the first aphid control by ladybirds appeared. From then on, the necessity for insecticides diminished, although some treatment continued into June. It appears that the spotted alfalfa aphid has passed through the population surge that followed its introduction, and is now settling down to an annual pattern. 


\section{LITERATURE CITED}

BöRNER, C.

1952. Europae centralis Aphides, Thüringischen Botanischen Gesellschaft, Heft 4 und Mitteilungen, Beiheft 3: 1-484.

BuckToN, G. B.

1899. Notes on two species of aphids. Indian Mus. Notes 4(5): 277.

DAS, B.

1918. The Aphididae of Lahore. Indian Mus. Memoirs 6(1) : 135-274.

Davis, J. J.

1908. Studies on Aphididae I. Ent. Soc. Amer. Ann. 1: 251-64.

1910. A list of the Aphididae of Illinois, with notes on some of the species. Jour. Econ. Ent. 3: 419.

1914. The yellow clover aphis. U. S. Dept. Agr., Bur. Ent. Tech. Ser. 25 : 17-40.

DeLepinex, J., and J. Mimeur

1932. Notes d'entomologie agricole et forestiere du Maroc. Mem. de la Soc. Nat. du Maroc. 31: 1-195.

Folsom, J. W.

1909. Insect pests of clover and alfalfa. 25th Report of the State Entomologist on the Noxious and Beneficial Insects of the State of Illinois, pp. 41-124.

GILLETPE, C. P.

1910. Plant louse notes, Family Aphididae. Jour. Econ. Ent. 3: 367-71.

HaLL, W. J.

1926. Notes on the Aphididae of Egypt. Egyptian Min. Agr. Tech. and Sci. Serv. Bul. 68: 1-62.

HoTTES, F. C., and T. H. Frison

1931. The plant lice, or Aphiidae, of Illinois. Illinois Nat. Hist. Survey Bul. 19 : 121-447. KALTENBACH, J. H.

1846. Fünf neue Species aus der Familie der Pflanzenläuse. Entomologische Zeitung, Stettin. 7: 169-75.

MONELL, J.

1882. Notes on Aphididae. Canadian Ent. 16: 13-16.

NevsKy, V. P.

1929. The aphids of central Asia [In Russian]. Uzbek. Exp. Plant Prot. Sta. No. 16: 1-424, 108 figs. (pgs. 309, 316-18).

Osborn, H., and F. A. SIRRINE

1893. Notes on Aphididae. Insect Life 5: 235-37.

Passerini, G.

1863. Aphididae Italicae Hucusque Observatae. Archivo per la Zoologia, l'Anatomia, e la Fisiologia. 2(2) : 129-212.

SANBoRn, C. E.

1906. Kansas Aphididae with catalogue of North American Aphididae and host plant list. Kansas Univ. Sci. Bul. 3(8) : 251-62.

Theobald, F. V.

1915. African Aphididae, Part II. Bul. Ent. Res. 6 : 103-53.

1923. New species of British aphids. Ent. Monthly Mag. 59: 23-28.

1927. The plant lice or Aphididae of Great Britain. 2: 411 pp. Headley Bros., Ashford, Kent.

Tsing, S., and CHIA-CHU TAO

1936. Aphid. of China. Ent. and Phytopath. 4: 120-76 (pg. 161).

TUTTLE, D. M., and G. D. BUTler, JR.

1954. The yellow clover aphid-a new alfalfa pest in the southwest. Jour. Econ. Ent. $47(6): 1157$. 
The journal Hilgardia is published at irregular intervals, in volumes of about 600 pages. The number of issues per volume varies.

Subscriptions are not sold. The periodical is sent as published only to libraries, or to institutions in foreign countries having publications to offer in exchange.

You may obtain a single copy of any issue free, as long as the supply lasts; please request by volume and issue number from:

\section{Agricultural Publications \\ Room 22, Giannini Hall \\ University of California \\ Berkeley 4, California}

The limit to nonresidents of California is 10 separate issues on a single order. A list of the issues still available will be sent on request.

In our publications it is sometimes convenient to use trade names of products or equipment rather than scientific identifications. In so doing it is unavoidable in some cases that similar products which are on the market under other trade names may not be cited. No endorsement of named products is intended nor is criticism implied of similar products which are not mentioned. 


$$
\begin{aligned}
& \text { (1) }
\end{aligned}
$$

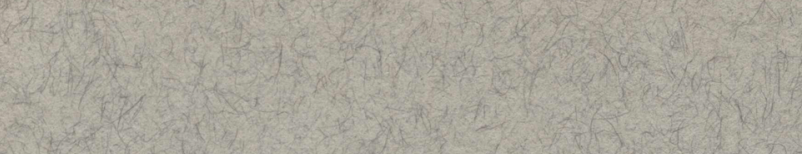

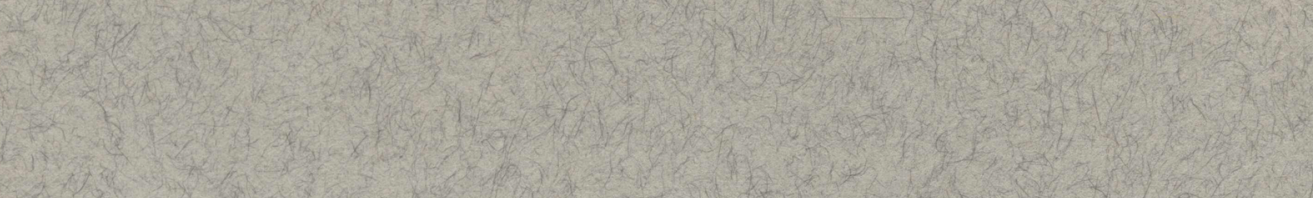

$$
\begin{aligned}
& \lim _{2}+x+4
\end{aligned}
$$

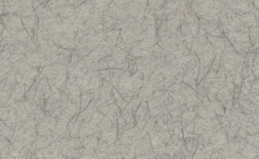

$$
\begin{aligned}
& \text { (i) finte } \\
& \text { (1) } \\
& \text { in }
\end{aligned}
$$

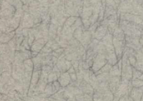

$$
\begin{aligned}
& \text { (2) }
\end{aligned}
$$

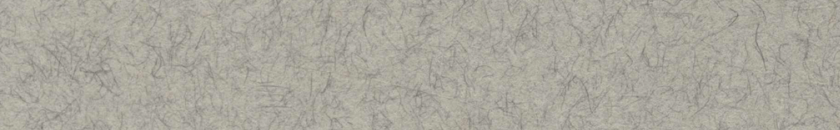

$$
\begin{aligned}
& \text { (a) } x, 2 \text { in }
\end{aligned}
$$

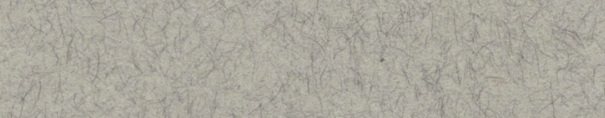

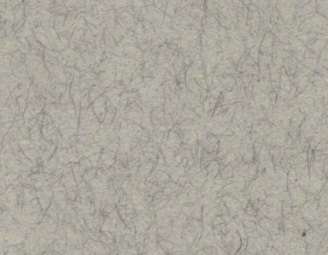

